\title{
Seasonal dynamics of stable isotopes and element ratios in authigenic calcites during their precipitation and dissolution, Sacrower See (northeastern Germany)
}

\author{
Philipp BLUSZCZ*, Andreas LÜCKE ${ }^{1)}$, Christian OHLENDORF and Bernd ZOLITSCHKA \\ Geopolar, Geomorphology and Polar Research, Institute of Geography, University of Bremen, Celsiusstr. FVG-M, 28359 Bremen, \\ Germany \\ ${ }^{1)}$ Energy \& Environment, Institute of Chemistry and Dynamics of the Geosphere 4: Agrosphere, Research Center Jülich, 52425 \\ Jülich, Germany \\ *e-mail corresponding author: bluszcz@uni-bremen.de
}

\begin{abstract}
The seasonal evolution of chemical and physical water properties as well as particle fluxes was monitored in Sacrower See (northeastern Germany) during two consecutive years (Oct 2003 - Oct 2005). Additonally, we measured $\delta^{18} \mathrm{O}$ and $\delta^{13} \mathrm{C}$ as well as $\mathrm{Sr}: \mathrm{Ca}$ and $\mathrm{Mg}: \mathrm{Ca}$ ratios of authigenic calcites that were collected in sequencing sediment traps in order to disentangle environmental and climatic factors controlling these parameters. In particular, our aim was to find out if element ratios and the isotopic composition of calcites reflect changes in water and air temperatures. Lake water is highly enriched in ${ }^{18} \mathrm{O}(-1.3$ to $-2.5 \%$ o VSMOW) with an evaporative increase of 0.6\% during summer. Values are 5-6\% more positive than groundwater values and 4-5\%o more positive than long-term weighted annual means of precipitation. During spring and summer, high amounts of dissolved phosphate cause eutrophic conditions and calcite precipitation in isotopic disequilibrium. Measured values are depleted in ${ }^{18} \mathrm{O}$ by 2 to $10 \%$ compared to calculated equilibrium values. Resuspension and partial dissolution of calcite in the water column contribute to this isotopic divergence in summer and autumn as $\delta^{18} O_{c a}$ and $\delta^{13} C$ values increased in the hypolimnion during this time. Mg:Ca and $S r: C a$ ratios are altered by dissolution as well. In the hypolimnion these ratios were higher than in the epilimnion. Another reason for the huge deviation between measured and theoretical $\delta^{18} O_{c a}$ values during summer is the occurrence of large amounts of Phacotus lenticularis in the carbonate fraction. High amounts of Phacotus lead to more negative $\delta^{18} \mathrm{O}_{c a}$ and more positive $\delta^{13} \mathrm{C}$ values. Several characteristics of $\delta^{18} \mathrm{O}_{c a}$ and $\delta^{13} \mathrm{C}$ are also reflected by $\mathrm{Mg}: \mathrm{Ca}$ and $\mathrm{Sr}$ :Ca ratios and isotopic composition of oxygen and carbon were influenced by the onset and stability of stratification. Especially the earlier onset of stratification in 2005 caused higher sediment fluxes and more positive carbon and oxygen isotope values of bioinduced carbonates compared to 2004.
\end{abstract}

Key words: sediment trap, high-resolution particle flux, seasonality, oxygen isotopes, carbon isotopes, hardwater lake

\section{INTRODUCTION}

Reconstruction of palaeoclimatic and palaeoenvironmental information demands a well dated undisturbed archive, feasible proxy-parameters, analytical precision and an understanding of the processes that formed the archive. This is especially the case for stable isotopes and element ratios because these may be influenced by different parameters.

Stable isotopes in biogenic and authigenic carbonates were used for palaeoclimatic reconstructions for decades, mainly in the marine environment (Wefer et al. 1999), but also from speleothems (e.g., McDermott 2004; Fairchild et al. 2006), and as well from lake sediments (e.g., Stuiver 1970; Fronval et al. 1995; Teranes et al. 1999a).

Variations of $\delta^{13} \mathrm{C}$ values of precipitated calcite in general are a reflection of $\delta^{13} \mathrm{C}$ values of the DIC (Dissolved Inorganic Carbon). $\delta^{13} \mathrm{C}$ of DIC is controlled by the isotopic composition of incoming waters, the exchange of $\mathrm{CO}_{2}$ between lake surface waters and the atmosphere, by photosynthesis and respiration of algae and aquatic macrophytes and by organic matter decomposition (McKenzie 1985; Lee et al. 1987; Teranes \& Bernasconi 2005) as well as by carbonate dissolution in the water column.

Primarily, variations of $\delta^{18} \mathrm{O}$ in calcites $\left(\delta^{18} \mathrm{O}_{\text {ca }}\right)$ represent changes in the isotopic composition and temperature of the ambient water. Accordingly, they can potentially be used as palaeothermometers, for the reconstruction of changes in the precipitation/evaporation ratio or the isotopic composition of inflows which control $\delta^{18} \mathrm{O}$ of the lake water $\left(\delta^{18} \mathrm{O}_{\text {water }}\right.$; Leng \& Marshall 2004).

The analysis of element ratios like magnesium to calcium $(\mathrm{Mg}: \mathrm{Ca})$ and strontium to calcium $(\mathrm{Sr}: \mathrm{Ca})$ in carbonates is rare in paleolimnology. They were used first and today still are commonly applied as a paleothermometer in the marine environment, especially from coral skeletons (Beck et al. 1992; Mitsuguchi et al. 1996). In the past $\mathrm{Mg}: \mathrm{Ca}$ and $\mathrm{Sr}: \mathrm{Ca}$ ratios were determined in freshwater ostracod shells where they may reflect water salinity (Holmes \& Chivas 2002; Anadón et al. 2007). Ostracod $\mathrm{Mg}: \mathrm{Ca}$ ratios were linked to water temperatures (Dwyer et al. 2002) in environments 


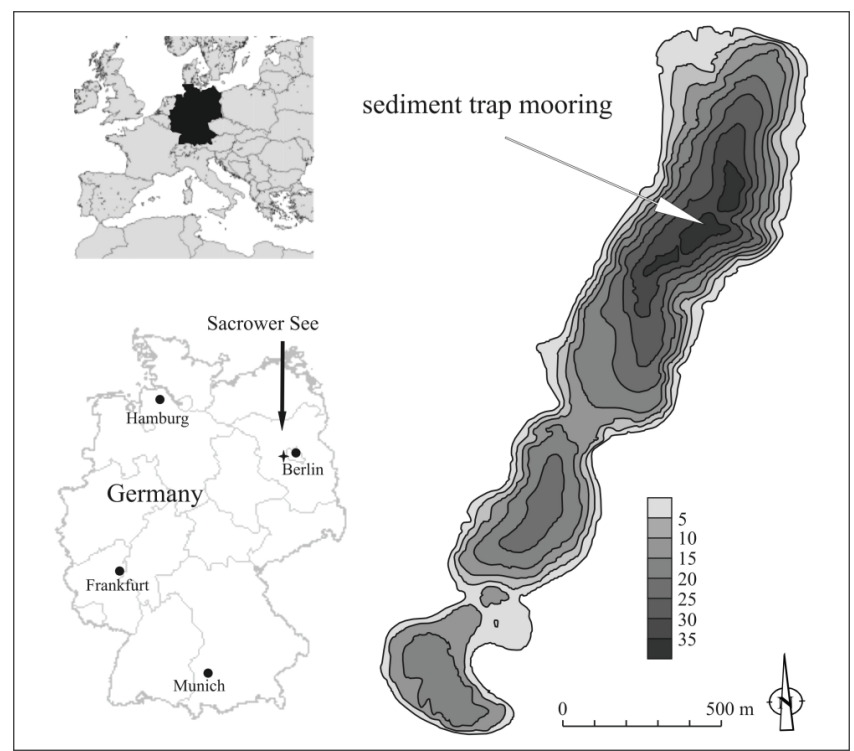

Fig. 1. Bathymetric map of Sacrower See. Position of the sediment trap mooring with geographic location in Germany and Europe indicated in the left panels.

where $\mathrm{Mg}: \mathrm{Ca}$ ratios do not change over time. There are very few attempts to compare the results of ostracod elements to authigenic carbonates (Müller et al. 1972; Haskell et al. 1996; Crausbay et al. 2006). Investigations exclusively carried out on authigenic carbonates are very rare (Lemcke \& Sturm 1997; Wick et al. 2003).

$\delta^{18} \mathrm{O}, \delta^{13} \mathrm{C}$ and element ratios of carbonates are influenced by complex and interlinked environmental processes. The interpretation of $\delta^{18} \mathrm{O}$ values from lake carbonates is based on the assumption of isotopic equilibrium between water and carbonate according to equilibrium fractionation equations determined by laboratory experiments (Tarutani et al. 1969; Kim \& O'Neil 1997). Carbonates do not always precipitate in isotopic equilibrium with ambient waters as they are often influenced by the use of fertiliziers in agriculture (mainly phosphate) of the catchment area. It is essential to determine this individually for each site however, isotopic disequilibrium must not be the case for the whole sediment record. Hitherto, not all reasons for isotopic disequilibrium are clear. Fronval et al. (1995) reported isotopically depleted oxygen isotope values relative to calculated equilibrium values in Lake Arresø, Denmark, which are possibly caused by a high level of eutrophication in this lake. Teranes et al. (1999a) showed that calcites of Baldeggersee, Switzerland, precipitated in isotopic equilibrium during summer only. This was also reported for Lake Neuchâtel, Switzerland (Filippi et al. 1998). Teranes et al. (1999) could show that the trophic state of the lake and equilibrium/disequilibrium are related.

The study of modern processes enables us to improve our understanding of the formation of annual laminations under varying conditions. It is crucial to understand which of the biological, chemical or physical factors dominate the archived palaeoclimatic and envi- ronmental information as these factors may vary considerably from one lake to another.

The annually laminated sediments of Sacrower See are most suitable for such studies as they fulfill most of the above mentioned requirements (undisturbed archive, etc.) and provide a high potential for the investigation of environmental parameters that influence the evolution of isotope ratios of oxygen and carbon as well as element ratios of authigenic lacustrine carbonates.

For the carbonates of Sacrower See, collected in sediment traps, we tried to determine how carbon and oxygen isotopes are influenced by meteorological and lake internal parameters. Meteorological, limnological and geochemical data in combination with isotope data from the GNIP-station Berlin (GNIP: Global Network for Isotopes in Precipitation) enabled us to evaluate which processes control the isotopic composition during different seasons. The isotopic composition of carbonates was compared with air and water temperatures and with $\mathrm{Sr}: \mathrm{Ca}$ and $\mathrm{Mg}: \mathrm{Ca}$ ratios in order to ascertain if element ratios and stable isotopes can be used as indicators of past climatic parameters at Sacrower See. In addition, we discuss how dissolution processes and resuspension within the water column influence these parameters. The results of the study will help to understand the paleoclimatic and paleoenvironmental information stored in the sediments of Sacrower See.

\subsection{Lake description and hydrology}

Sacrower See is located in Brandenburg (northeastern Germany) $5 \mathrm{~km}$ northeast of Potsdam and $10 \mathrm{~km}$ west of Berlin $\left(13.06^{\circ} \mathrm{E}, 52.27^{\circ} \mathrm{N}, 29.5 \mathrm{~m}\right.$ a.s.1.). The lake is 250 to $500 \mathrm{~m}$ wide (mean $400 \mathrm{~m}$ ), has a length of $2.7 \mathrm{~km}$ and is subdivided into three basins (Fig. 1). A detailed description of the site is given by Lüder et al. (2006). 
The lake and its catchment area were formed during the Weichselian glacial period (Marine isotope stage 2). The size of the forested catchment area $\left(35.3 \mathrm{~km}^{2}\right)$ represents the sum of the catchment areas of Sacrower See $\left(7.9 \mathrm{~km}^{2}\right)$ and Groß Glienicker See $\left(27.4 \mathrm{~km}^{2}\right)$. The main tributary is a subsurface inflow with a volume of $0.5410^{6} \mathrm{~m}^{3} \mathrm{a}^{-1}$ that originates from Groß Glienicker See to the northeast. Mean water residence time of Sacrower See is $12-15$ years (Rümmler et al. 1997). Through an $0.6 \mathrm{~km}$ long artificial channel that connects Sacrower See to the River Havel, the lake received high nutrient input during periods of increased water level of the River Havel. It is unknow when this connection was established. Schönfelder (1997) demonstrated that there has been an increasing phosphorus load since the $12^{\text {th }}$ Century and heavy phosphorus input during the $20^{\text {th }}$ Century by using diatoms from Havel sediments as indicators. In 1986 the connection to the Havel was blocked by a stop valve to prevent the nutrient flow. Nevertheless, nutrient input remained high because of subsurface and groundwater inflow from eutrophic Groß Glienicker See. At the beginning of the 1990s lake restoration projects were started for Groß Glienicker See as well as for Sacrower See. The hypolimnion of both lakes has been treated with deep-water aeration from 1992 to 1996 in order to stop ongoing eutrophication processes at Sacrower See, which is a nature protection area since the early 1940s (Rümmler et al. 1997). The sediments of Sacrower See mainly consist of organic matter, calcite, biogenic silica and only a small amount of minerogenic material. They are classified as organicrich calcareous gyttja. Sacrower See has been forming annually laminated sediment since AD 1872 (Lüder et al. 2006) with varves composed of several distinct seasonal layers (Bluszcz et al. 2008).

\subsection{Limnology}

Sacrower See is a dimictic and holomictic lake with a maximum depth of $37 \mathrm{~m}$. It has a water volume of $0.0151 \mathrm{~km}^{3}$ and a surface area of $1.02 \mathrm{~km}^{2}$. During the sampling period it was stratified between mid-April and mid-October 2004 and from May 2005 until October 2005. The thermocline was located between 6 and $8 \mathrm{~m}$. During summer stratification epilimnic temperatures mostly varied between 15 and $25{ }^{\circ} \mathrm{C}$ with a maximum temperature of $26.6^{\circ} \mathrm{C}$. An inverse stratification with 1$2{ }^{\circ} \mathrm{C}$ at the surface and $4{ }^{\circ} \mathrm{C}$ at the lake bottom has been observed only for short intervals between January and March 2004 as well as between February and March 2005 as ice cover is not a general feature in every year (Bluszcz et al. 2008).

The mean $\mathrm{pH}$ for the whole water body varied between 7 and 8. From April to July 2004 and from March to June 2005 epilimnic $\mathrm{pH}$ reached values between 8.1 and 9.5. Oxygen concentrations of the surface water were $11-15 \mathrm{mg} \mathrm{L}^{-1}$ during summer. Bottom waters were anoxic except during periods of holomixis (Bluszcz et al. 2008).

Maximum total phosphate (TP) concentrations measured in epilimnic waters during spring were $0.9 \mathrm{mg}$ $\mathrm{L}^{-1}$ in 2004 compared to $0.7 \mathrm{mg} \mathrm{L}^{-1}$ in 2005 and 3 times higher than e.g. in Baldeggersee (Niessen \& Sturm 1987). With the beginning of lake stratification, values dropped markedly. From May until September 2004 and from June until October 2005 concentrations of TP were very low or below detection limit in the epilimnion. High TP contents in the hypolimnion occurred from November 2003 until March 2004 (up to $4.6 \mathrm{mg} \mathrm{L}^{-1}$ ) and from October 2004 until February 2005 (up to 4.0 $\mathrm{mg} \mathrm{L}^{-1}$ ). This indicates strong eutrophic conditions due to re-dissolution of phosphate from the sediments. Calcite saturation indices $(\Omega)$ were elevated after mixis in spring (up to 14, Bluszcz et al. 2008). This oversaturation slowly decreased after calcite precipitation started. Two main diatom blooms were determined in Sacrower See. One occurred during spring, consisting of centric diatoms (mainly Stephanodiscus spp.) and one during late summer and autumn established by pennate diatoms like Asterionella formosa and Fragilaria spp. (Kirilova et al. 2008). Smear slide analyses of sediment trap samples revealed high amounts of the calcified green algae Phacotus lenticularis which may represent up to one third of the total calcite flux (Bluszcz et al. 2008).

\section{MATERIAL AND METHODS}

Samples of settling particles were obtained from October 2003 until October 2005 (observation period of 733 days) with two types of sediment traps. (1) We used six self-made integrating traps (Z1-Z6), each consisting of two parallel transparent PVC-liners, $60 \mathrm{~mm}$ in diameter and $650 \mathrm{~mm}$ in length with caps at the bottom (active area: $57 \mathrm{~cm}^{2}$ ). They were moored to a prestretched rope at the deepest part of the northern basin (Fig. 1) in water depths of 5, 13, 20, 25, 30, and $33 \mathrm{~m}$ $\left(13^{\circ} 06^{\prime} \mathrm{E}, 52^{\circ} 27^{\prime} \mathrm{N}\right)$. Each trap was attached to the mooring with a clamp at the top and a thin rope at the bottom to ensure an upright position. (2) For detailed high resolution sampling in the hypolimnion ( $3 \mathrm{~m}$ above the sediment-water interface) we installed a sequential sediment trap (S-trap) with a computer programmable sample bottle carrousel (PPS 4/3, 12 sample bottles, Technicap, France) in a water depth of $33 \mathrm{~m}$ (active area: $500 \mathrm{~cm}^{2}$ ). Trap exposure times varied between 3 and 14 days for single S-trap intervals and between 47 and 131 days for Z-traps. Altogether, we recovered 120 S-trap samples and 59 Z-trap samples during ten field campaigns. Samples have been decanted and freeze dried for 72 hours. Sediment fluxes were calculated (Eq. 1) with the active area defined as the open surface of the traps (funnel or cylinder) according to:

Sediment flux $\left(\mathrm{g} \mathrm{m}^{-2} \mathrm{~d}^{-1}\right)=\frac{\text { Dry net weight }[\mathrm{g}]}{\text { Active area }\left[\mathrm{m}^{2}\right] \mathrm{x} \text { Time }[\mathrm{d}]}$ 
Additionally, six thermistors (Minilog, Vemco, Canada) were attached to the mooring in water depths of 0 , $5,10,13,16,20$, and $33 \mathrm{~m}$ to study the mixing regime of Sacrower See. The topmost thermistor was fixed to the deep water aeration installation (not operating) just below the water surface and considered as $0 \mathrm{~m}$. All thermistors logged water temperatures at 30 minute intervals. For detailed results of the temperature analysis confer to Bluszcz et al. (2008).

A total of 137 water samples have been taken with an Uwitec water sampler (5 1, Uwitec, Austria) in depths of $0,2.5,5,7.5,10,15,20,25,30$, and $33 \mathrm{~m}$ during 11 field trips. Meteorological data from the long-term meteorological station Potsdam-Telegrafenberg was used for comparison with sediment flux and water column data. The station is situated in the south-western part of Potsdam at $81 \mathrm{~m}$ a.s.l. in a distance of $7 \mathrm{~km}$ from Sacrower See. $\delta^{18} \mathrm{O}$ values of precipitation $\left(\delta^{18} \mathrm{O}_{\mathrm{p}}\right)$ were derived from the Global Network of Isotopes in Precipitation (GNIP) from the station Berlin determined by the Institute of Groundwater Ecology of the National Research Centre for Environment and Health in Neuherberg, Germany.

Lake water samples from the northern basin and 2 groundwater samples from the western shore of the lake were analyzed for their oxygen isotopic composition at the Environmental Institute of the Research Center Jülich (Institute of Chemistry and Dynamics of the Geosphere) in accordance with IAEA (International Atomic Energy Agency) guidelines. $1 \mu \mathrm{L}$ aliquots of water samples were pyrolized at $1450{ }^{\circ} \mathrm{C}$ in a high-temperature (HT) oxygen analyzer (HEKAtech) and flushed online in He-carrier-gas to an Isoprime (GV Instruments) isotope ratio mass spectrometer. After removing reaction gases, the isotopic composition of the generated $\mathrm{CO}$ was measured and expressed in terms of $\delta$-values as per mill deviations from the international VSMOW (Vienna Standard Mean Ocean Water) standard. Analytical precision of the $\delta^{18} \mathrm{O}_{\text {water }}$ measurements was within $0.15 \%$.

Carbon and oxygen isotopic composition of carbonates from sediment trap material were also measured at the Environmental Institute of the Research Center Jülich, Germany. The sediment trap samples were pretreated with $\mathrm{NaOCl}$ (6-14\% active chlorine) to remove organic material. Then they were reacted in orthophosphoric acid at $90{ }^{\circ} \mathrm{C}$ for at least 1 hour. Isotopic ratios of the $\mathrm{CO}_{2}$ gas were then measured on-line by an Isoprime (GV Instruments) mass spectrometer. Isotope composition is expressed in the $\delta$ notation as per mill deviations from the international VPDB (Vienna Pee Dee Belemnite) standard. Analytical precision based on routine analysis of an internal reference standard (Carrara Marble) was within $0.15 \%$ for $\delta^{18} \mathrm{O}_{\mathrm{ca}}$ and $0.1 \%$ for $\delta^{13} \mathrm{C}$.

Equilibrium oxygen isotopic composition for Sacrower See carbonates was calculated using the ambient water temperature of the precipitated carbonates, the isotopic composition of the Sacrower See surface water and the revised temperature dependent oxygen isotope equilibrium fractionation equation between calcite and water from Kim \&O'Neil (1997):

$$
1000 \ln \alpha\left(\text { Calcite- } \mathrm{H}_{2} \mathrm{O}\right)=18.03\left(10^{3} \mathrm{~T}^{-1}\right)-32.42
$$

where $\alpha$ is the fractionation factor, and $\mathrm{T}$ is water temperature in degree Kelvin. The conversion from VSMOW to PDB was calculated after Coplen et al. (1983):

$$
\delta^{18} \mathrm{O}_{\text {water }}(\mathrm{PDB})=(0.97002 \mathrm{VSMOW})-29.98
$$

Constitution of $1000 \ln \alpha$ for a given temperature $\mathrm{T}$ and the measured $\delta^{18} \mathrm{O}_{\text {water }}$ in PDB (equations 2 and 3) into equation 4 provides the respective theoretical equilibrium isotopic composition.

$$
\begin{gathered}
\delta^{18} \mathrm{O}_{\text {calculated }}=1000 \ln \alpha\left(\text { Calcite- } \mathrm{H}_{2} \mathrm{O}\right)+ \\
+\delta^{18} \mathrm{O}_{\text {water }}(\mathrm{PDB})
\end{gathered}
$$

Temperature (T) in degree Kelvin was calculated as the mean of the measured temperatures in 0 and $5 \mathrm{~m}$ water depth, where calcite precipitation takes place (Bluszcz et al. 2008). $\delta^{18} \mathrm{O}_{\text {water }}$ was calculated by linear interpolation between measured data. For every trap interval the pair of corresponding $\mathrm{T}$-values and $\delta^{18} \mathrm{O}_{\text {water }}$ was used to calculate the equilibrium isotopic composition applying equation 4.

The elemental composition of carbonates (a mixture of bioinduced calcite and phacotus shells) was determined after a modified method described by Lemcke \& Sturm (1997). We used an acetic acid disintegration (AAD) method to dissolve only the carbonate fraction of the sediment trap samples. $5 \mathrm{ml}$ of $0.35 \mathrm{~mol} \mathrm{~L}^{-1}$ acetic acid was added to $25 \mu \mathrm{g}$ of freeze-dried sediment. The samples were disintegrated in $20 \mathrm{~mL}$ pre-cleaned centrifuge tubes under constant shaking for 120 minutes. The suspension was cleared by ultra centrifugation at 4472 $\mathrm{G}$ for 10 minutes. $1 \mathrm{~mL}$ of the clear supernatant was added to $0.5 \mathrm{ml}$ of $\mathrm{HNO}_{3}$ (conc) and $15 \mathrm{~mL}$ of doubly distilled water into a $30 \mathrm{ml}$ Sarstedt PP-tube. The elements $\mathrm{Ca}, \mathrm{Mg}$ and $\mathrm{Sr}$ were determined simultaneously on an IRIS Intrepid ICP-OES (Inductively Coupled Plasma Optical Emission Spectrometer) at the Geosciences/Glaciology Section of the Alfred Wegener Institute for Polar and Marine Research in Bremerhaven, Germany. Three internal standards were measured every ten samples for quality control. Precision was $<0.5 \%$ rsd for $\mathrm{Ca}$ and $\mathrm{Mg}$ and $<1.5 \%$ rsd for $\mathrm{Sr}$. Element amounts in $\mathrm{mg} \mathrm{L}^{-1}$ were used to calculate ratios by considering molar masses and multiplied by 1000 to simplify presentation.

\section{RESULTS}

\section{1. $\delta^{18} \mathrm{O}$ of lake water, groundwater and precipitation}

The oxygen isotope composition of the lake water $\left(\delta^{18} \mathrm{O}_{\text {water }}\right)$ showed three distinct maxima in the epilimnion in October 2003 (-1.4\%o), August/September 2004 (-1.3\%) and August 2005 (-1.8\%o, Fig. 2). Mini- 


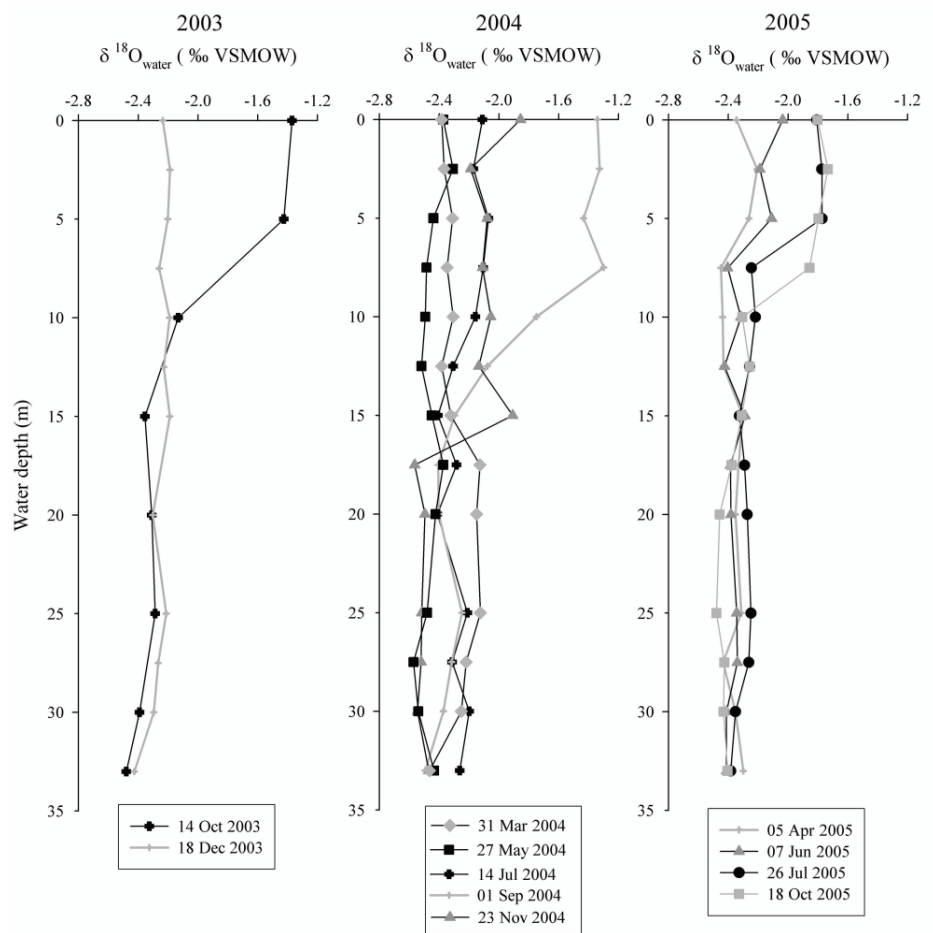

Fig. 2. Depth profiles of $\delta^{18} \mathrm{O}_{\text {water }}$ of Sacrower See from October 2003 until October 2005.

mum epilimnic values were recorded at the beginning of April 2004 and April 2005 (-2.4\%). Bottom waters were between -2.1 and $-2.6 \%$ during the sampling period. In May $2004 \delta^{18} \mathrm{O}_{\text {water }}$ was almost at the same value in the whole water column (around -2.4\%o VSMOW), whereas in May 2005 the $\delta^{18} \mathrm{O}$ values within the water column was not so uniform. An overall evaporative increase of $0.6 \%$ occurred during summer.

$\delta^{18} \mathrm{O}_{\mathrm{p}}$ from the GNIP-station in Berlin showed a weighted mean of $-7.8 \%$ for the last 27 years (19782005 ) which was considerably more negative than lake water values. $\delta^{18} \mathrm{O}$ values of the groundwater samples were -8.7 and $-8.8 \%$.

\section{2. $\delta^{13} \mathrm{C}$ and $\delta^{18} \mathrm{O}$ of carbonates from sediment trap samples}

For a better understanding of processes in the water column we used two different types of traps in different water depths. This enabled us to verify time lags between calcite precipitation in the surface waters and deposition at the lake bottom.

The amount of calcite in the Z-trap samples was small and some samples were too small for isotope analysis (Fig. 3a). Values of $\delta^{13} \mathrm{C}$ varied between $2 \%$ and $-26.9 \%$ VPDB. Samples of the second trap interval from December 2003 to April 2004 showed the most negative values with to the lowest value of $-26.6 \%$ in the uppermost trap (Z1 at $5 \mathrm{~m}$ ) and $-19.0 \%$ in the lowest trap (Z6 at 33 m, Tab. 1).

Oxygen isotope values of calcite in the Z-traps exhibited a high variability over the period of investiga- tion (Fig. 3b). Similar to $\delta^{13} \mathrm{C}$ values, the oxygen isotopic values of several samples could not be determined due to lack of sufficient material, in particular, samples of the first and fifth interval (Tab. 2).

$\delta^{13} \mathrm{C}$ values of calcite from S-trap samples showed several similar characteristics to those of the Z-traps (Fig. 4a). Nevertheless, there were distinct differences. Early spring values had a $\delta^{13} \mathrm{C}$ value of about $-13.5 \%$ (pooled samples). Beginning at the end of March values decreased rapidly to less than $-20 \%$ and finally reached $-21.9 \%$ during the middle of May (Tab. 3). Thereafter, they varied between $-4.6 \%$ and $-2.1 \%$ until the middle of October 2004. The second year of investigation began with a steady decrease from October 2004 (Fig. 4b) to March 2005 (-20.5\%o). Isotopic composition then increased to $-4.9 \%$ and in analogy to spring 2004, decreased until the end of May (-23.16\%). In June $\delta^{13} \mathrm{C}_{\mathrm{cc}}$ values increased to $0 \%$, followed by a large but short-lived decrease to $-11.5 \%$. From August until October $\delta^{13} \mathrm{C}$ values were high varying between 0.1 and $1.5 \%$.

The S-trap samples provided a high resolution record of $\delta^{18} \mathrm{O}$ for two complete annual cycles (Fig. 4b). Due to the lack of sufficient sediment during times of reduced sediment fluxes, analysis of a few samples was impossible (e.g., October 2003 - February 2004) or samples had to be pooled (Tab. 3).

Calculated oxygen isotope equilibrium values based on measured surface water temperature and $\delta^{18} \mathrm{O}$ of water showed the same characteristics for both years of investigation with high values during autumn, winter and spring, and low values during the summer months. 

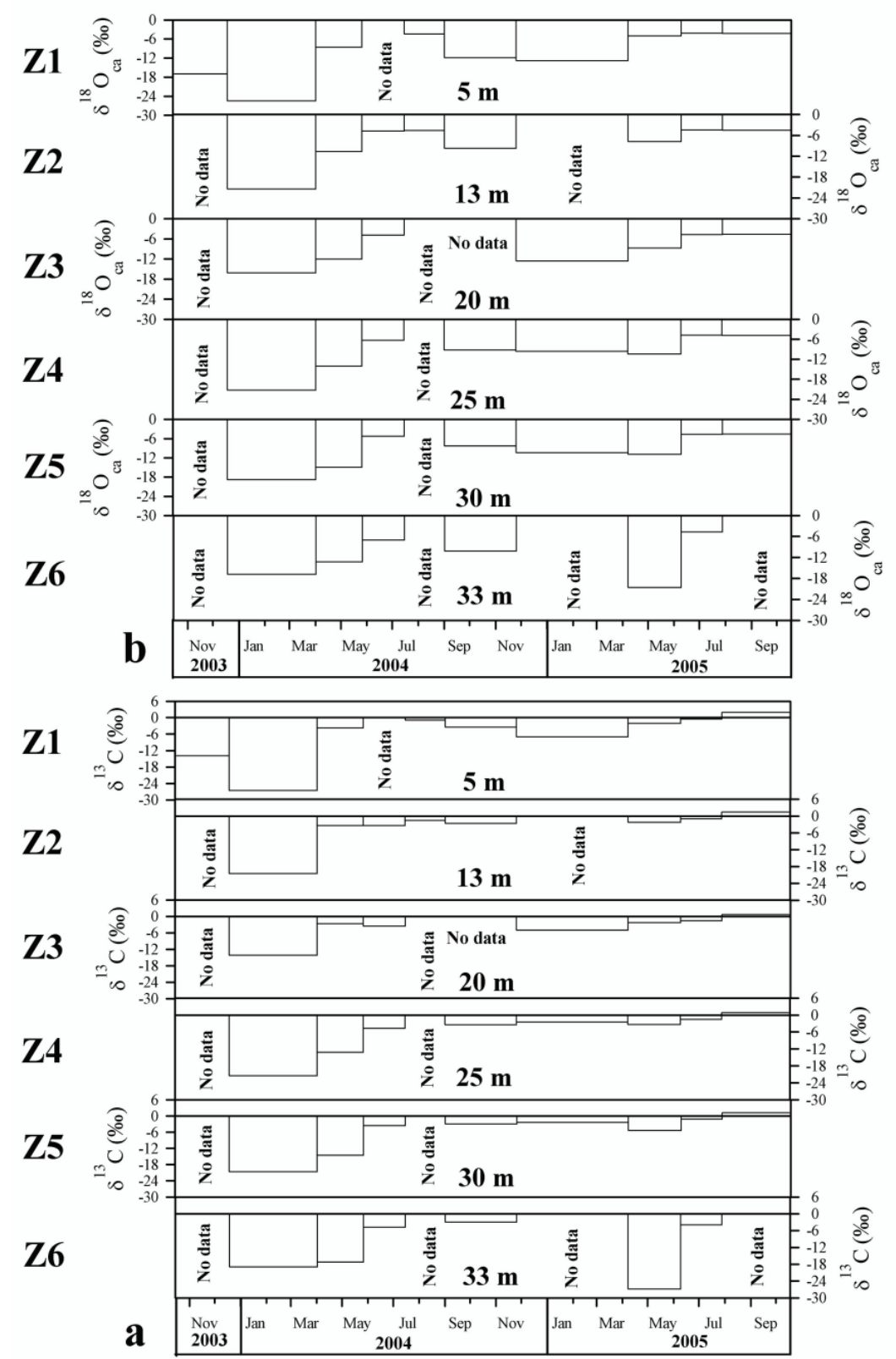

Fig. 3. $\delta^{13} \mathrm{C}(\mathbf{a})$ and $\delta^{18} \mathrm{O}(\mathbf{b})$ of carbonates from cylindrical traps (Z-traps) at depths of 5, 13, 20, 25, 30 and $33 \mathrm{~m}$ from October 2003 until October 2005. "No data" indicates insufficient amount of material for stable isotope analysis.

Tab. 1. Carbon isotopes of carbonates from Z-traps $(Z 1-Z 6)$.

\begin{tabular}{cccccccc}
\hline $\begin{array}{c}\text { Date } \\
\text { IN }\end{array}$ & $\begin{array}{c}\text { Date } \\
\text { OUT }\end{array}$ & $\begin{array}{c}\text { Z1 } \\
5 \mathrm{~m}\end{array}$ & $\begin{array}{c}\text { Z2 } \\
13 \mathrm{~m}\end{array}$ & $\begin{array}{c}\text { Z3 } \\
20 \mathrm{~m}\end{array}$ & $\begin{array}{c}\text { Z4 } \\
25 \mathrm{~m}\end{array}$ & $\begin{array}{c}\text { Z5 } \\
30 \mathrm{~m}\end{array}$ & $\begin{array}{c}\text { Z6 } \\
33 \mathrm{~m}\end{array}$ \\
\hline 15.10.2003 14:00 & $18.12 .200314: 00$ & -13.91 & - & - & - & - & - \\
$18.12 .200317: 00$ & $01.04 .200414: 00$ & -26.56 & -20.57 & -14.15 & -21.49 & -20.67 & -19.02 \\
$01.04 .200418: 00$ & $26.05 .200414: 00$ & -3.82 & -3.44 & -2.70 & -13.18 & -14.50 & -17.19 \\
$26.05 .200418: 00$ & $15.07 .200412: 00$ & - & -3.42 & -3.61 & -4.66 & -3.55 & -4.77 \\
$15.07 .200417: 00$ & $31.08 .200414: 00$ & -0.91 & -1.57 & - & - & - & - \\
$01.09 .200410: 00$ & $24.11 .200410: 00$ & -3.47 & -2.62 & - & -3.49 & -2.94 & -2.96 \\
$25.11 .200415: 00$ & $06.04 .200511: 00$ & -7.07 & - & -5.05 & -2.55 & -2.41 & - \\
$07.04 .200514: 00$ & $08.06 .200512: 00$ & -2.12 & -2.29 & -2.30 & -3.35 & -5.34 & -26.92 \\
$09.06 .200512: 00$ & $27.07 .200512: 00$ & -0.59 & -1.00 & -1.58 & -1.54 & -1.24 & -3.95 \\
$28.07 .200512: 00$ & $17.10 .200512: 00$ & 1.99 & 1.37 & 0.66 & 0.85 & 1.23 & - \\
\hline
\end{tabular}


Tab. 2. Oxygen isotopes of carbonates from Z-traps $(\mathrm{Z} 1-\mathrm{Z6})$.

\begin{tabular}{cccccccc}
\hline $\begin{array}{c}\text { Date } \\
\text { IN }\end{array}$ & $\begin{array}{c}\text { Date } \\
\text { OUT }\end{array}$ & $\begin{array}{c}\text { Z1 } \\
5 \mathrm{~m}\end{array}$ & $\begin{array}{c}\text { Z2 } \\
13 \mathrm{~m}\end{array}$ & $\begin{array}{c}\text { Z3 } \\
20 \mathrm{~m}\end{array}$ & $\begin{array}{c}\text { Z4 } \\
25 \mathrm{~m}\end{array}$ & $\begin{array}{c}\text { Z5 } \\
30 \mathrm{~m}\end{array}$ & $\begin{array}{c}\text { Z6 } \\
33 \mathrm{~m}\end{array}$ \\
\hline 15.10.2003 14:00 & $18.12 .200314: 00$ & -17.06 & - & - & - & - & - \\
18.12.2003 17:00 & $01.04 .200414: 00$ & -25.49 & -21.45 & -16.14 & -21.24 & -18.88 & -16.81 \\
$01.04 .200418: 00$ & $26.05 .200414: 00$ & -8.58 & -10.73 & -12.07 & -14.15 & -14.93 & -13.27 \\
$26.05 .200418: 00$ & $15.07 .200412: 00$ & - & -4.78 & -4.95 & -6.37 & -5.29 & -7.07 \\
$15.07 .200417: 00$ & $31.08 .200414: 00$ & -4.39 & -4.63 & - & - & - & - \\
$01.09 .200410: 00$ & $24.11 .200410: 00$ & -11.94 & -9.76 & - & -9.28 & -8.35 & -10.20 \\
$25.11 .200415: 00$ & $06.04 .200511: 00$ & -12.85 & - & -12.63 & -9.60 & -10.44 & - \\
$07.04 .200514: 00$ & $08.06 .200512: 00$ & -5.00 & -7.78 & -8.76 & -10.46 & -10.93 & -20.61 \\
$09.06 .200512: 00$ & $27.07 .200512: 00$ & -4.21 & -4.47 & -4.76 & -4.79 & -4.70 & -4.71 \\
$28.07 .200512: 00$ & $17.10 .200512: 00$ & -4.25 & -4.58 & -4.68 & -4.92 & -4.65 & - \\
\hline
\end{tabular}

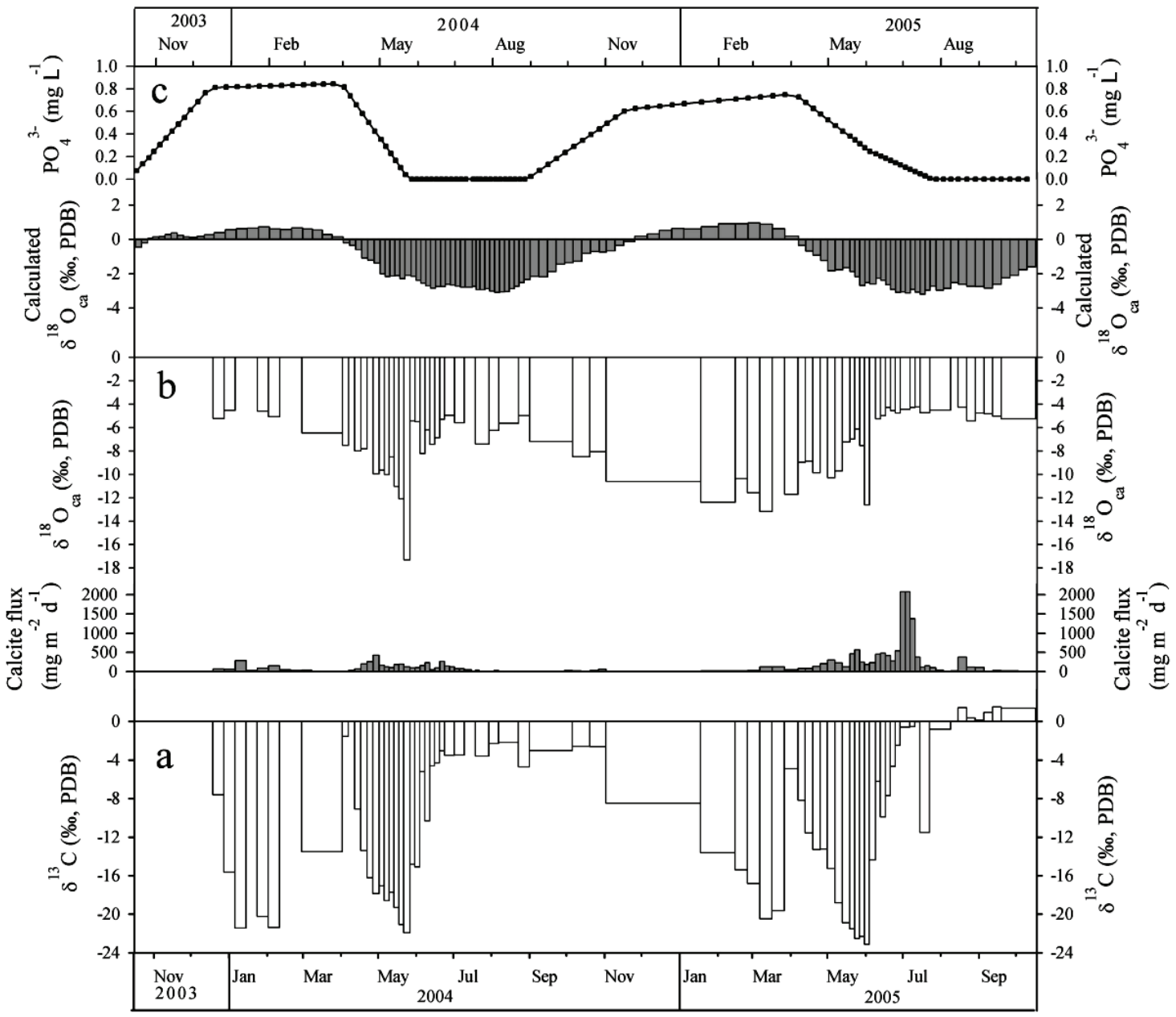

Fig. 4. $\delta^{13} \mathrm{C}$ (a) and $\delta^{18} \mathrm{O}$ of carbonates of the sequential sediment trap (S-trap) at the water depth of $33 \mathrm{~m}$ with calcite flux (b) and phosphate content in the surface waters as well as calculated equilibrium oxygen isotopic compositions (c) from October 2003 until October 2005. 
Tab. 3. Carbon and oxygen isotopes of carbonates of the S-trap samples (33 m).

\begin{tabular}{|c|c|c|c|c|}
\hline $\begin{array}{l}\text { Date } \\
\text { IN }\end{array}$ & $\begin{array}{l}\text { Date } \\
\text { OUT }\end{array}$ & $\begin{array}{c}\text { Oxygen Isotopes } \\
\delta^{18} \mathrm{O} \%\end{array}$ & $\begin{array}{c}\text { Carbon Isotopes } \\
\delta^{13} \mathrm{C} \%\end{array}$ & $\begin{array}{l}\text { pooled } \\
\text { sample }\end{array}$ \\
\hline $16.10 .200300: 00$ & 17.12 .2003 00:00 & - & - & \\
\hline $19.12 .200300: 00$ & $28.12 .200300: 00$ & -5.24 & -7.63 & \\
\hline $28.12 .200300: 00$ & $06.01 .200400: 00$ & -4.53 & -15.65 & \\
\hline 06.01.2004 00:00 & $15.01 .200400: 00$ & - & -21.46 & \\
\hline $15.01 .200400: 00$ & $24.01 .200400: 00$ & - & - & \\
\hline $24.01 .200400: 00$ & $02.02 .200400: 00$ & -4.61 & -20.23 & \\
\hline 02.02.2004 00:00 & $11.02 .200400: 00$ & -5.07 & -21.38 & \\
\hline 11.02.2004 00:00 & 29.02.2004 00:00 & - & - & \\
\hline $29.02 .200400: 00$ & 01.04.2004 00:00 & -6.48 & -13.51 & $\mathrm{x}$ \\
\hline $02.04 .200400: 00$ & 07.04.2004 00:00 & -7.54 & -1.56 & \\
\hline 07.04.2004 00:00 & $12.04 .200400: 00$ & - & - & \\
\hline 12.04.2004 00:00 & 17.04.2004 00:00 & -8.00 & -9.10 & \\
\hline 17.04.2004 00:00 & $22.04 .200400: 00$ & -7.83 & -13.41 & \\
\hline $22.04 .200400: 00$ & $27.04 .200400: 00$ & - & -16.22 & \\
\hline $27.04 .200400: 00$ & $02.05 .200400: 00$ & -9.97 & -17.86 & \\
\hline 02.05.2004 00:00 & 06.05.2004 00:00 & -9.65 & -17.08 & \\
\hline $06.05 .200400: 00$ & 10.05.2004 00:00 & -10.03 & -18.61 & \\
\hline 10.05.2004 00:00 & $14.05 .200400: 00$ & -8.52 & -17.74 & \\
\hline 14.05.2004 00:00 & 18.05.2004 00:00 & -11.04 & -19.31 & \\
\hline $18.05 .200400: 00$ & $22.05 .200400: 00$ & -12.09 & -21.08 & \\
\hline $22.05 .200400: 00$ & $26.05 .200400: 00$ & -17.33 & -21.93 & \\
\hline $27.05 .200400: 00$ & $31.05 .200400: 00$ & -5.42 & -14.84 & \\
\hline $31.05 .200400: 00$ & 04.06.2004 00:00 & -5.51 & -15.12 & \\
\hline 04.06.2004 00:00 & 08.06.2004 00:00 & -8.24 & -5.20 & \\
\hline $08.06 .200400: 00$ & $12.06 .200400: 00$ & -6.20 & -10.31 & \\
\hline 12.06.2004 00:00 & 16.06.2004 00:00 & -7.44 & -4.60 & \\
\hline 16.06.2004 00:00 & 20.06.2004 00:00 & -6.87 & -4.30 & \\
\hline 20.06.2004 00:00 & $24.06 .200400: 00$ & -5.30 & -3.04 & \\
\hline $24.06 .200400: 00$ & 02.07.2004 00:00 & -4.96 & -3.52 & $\mathrm{x}$ \\
\hline 02.07.2004 00:00 & 10.07.2004 00:00 & -5.60 & -3.47 & $\mathrm{x}$ \\
\hline 10.07.2004 00:00 & $14.07 .200400: 00$ & - & - & \\
\hline 16.07.2004 00:00 & 19.07.2004 00:00 & - & - & \\
\hline $19.07 .200400: 00$ & $30.07 .200400: 00$ & -7.43 & -3.61 & $\mathrm{x}$ \\
\hline 30.07.2004 00:00 & 07.08.2004 00:00 & -6.25 & -2.30 & $\mathrm{x}$ \\
\hline 07.08.2004 00:00 & $23.08 .200400: 00$ & -5.63 & -2.17 & $\mathrm{x}$ \\
\hline $23.08 .200400: 00$ & $31.08 .200400: 00$ & -5.00 & -4.70 & $\mathrm{x}$ \\
\hline $01.09 .200400: 00$ & $06.10 .200400: 00$ & -7.19 & -3.01 & $\mathrm{x}$ \\
\hline $06.10 .200400: 00$ & $20.10 .200400: 00$ & -8.51 & -2.58 & $\mathrm{x}$ \\
\hline $20.10 .200400: 00$ & $02.11 .200400: 00$ & -8.07 & -2.60 & $\mathrm{x}$ \\
\hline 02.11.2004 00:00 & 18.01.2005 00:00 & -10.62 & -8.47 & $\mathrm{x}$ \\
\hline 18.01.2005 00:00 & $15.02 .200500: 00$ & -12.40 & -13.64 & $\mathrm{x}$ \\
\hline 15.02.2005 00:00 & $25.02 .200500: 00$ & -10.36 & -15.41 & \\
\hline $25.02 .200500: 00$ & 07.03.2005 00:00 & -11.59 & -16.83 & \\
\hline $07.03 .200500: 00$ & $17.03 .200500: 00$ & -13.18 & -20.50 & \\
\hline 17.03.2005 00:00 & 27.03.2005 00:00 & - & -19.65 & \\
\hline 27.03.2005 00:00 & $06.04 .200512: 00$ & -11.70 & -4.89 & \\
\hline 07.04.2005 00:00 & 13.04.2005 00:00 & -8.98 & -8.20 & \\
\hline $13.04 .200500: 00$ & 19.04.2005 00:00 & -8.89 & -11.57 & \\
\hline 19.04.2005 00:00 & $25.04 .200500: 00$ & -9.87 & -13.29 & \\
\hline $25.04 .200500: 00$ & $01.05 .200500: 00$ & - & -13.22 & \\
\hline $01.05 .200500: 00$ & 07.05.2005 00:00 & -10.30 & -15.28 & \\
\hline 07.05.2005 00:00 & 13.05.2005 00:00 & -9.73 & -18.82 & \\
\hline $13.05 .200500: 00$ & $19.05 .200500: 00$ & -7.24 & -20.91 & \\
\hline 19.05.2005 00:00 & 23.05.2005 00:00 & -6.98 & -21.53 & \\
\hline $23.05 .200500: 00$ & $27.05 .200500: 00$ & -6.15 & -22.55 & \\
\hline 27.05.2005 00:00 & 31.05.2005 00:00 & -7.56 & -22.31 & \\
\hline $31.05 .200500: 00$ & $04.06 .200500: 00$ & -12.61 & -23.16 & \\
\hline 04.06 .2005 00:00 & 08.06.2005 00:00 & - & -14.37 & \\
\hline 09.06.2005 00:00 & $13.06 .200500: 00$ & -5.25 & -6.23 & \\
\hline 13.06.2005 00:00 & 17.06.2005 00:00 & -4.99 & -9.89 & \\
\hline 17.06.2005 00:00 & 21.06.2005 00:00 & -4.28 & -7.71 & \\
\hline $21.06 .200500: 00$ & $25.06 .200500: 00$ & -4.54 & -4.67 & \\
\hline $25.06 .200500: 00$ & $29.06 .200500: 00$ & -4.75 & -2.47 & \\
\hline 29.06.2005 00:00 & 07.07 .2005 00:00 & -4.45 & -0.58 & $\mathrm{x}$ \\
\hline 07.07.2005 00:00 & 11.07.2005 00:00 & -4.30 & -0.54 & \\
\hline $11.07 .200500: 00$ & $15.07 .200500: 00$ & -4.24 & -0.03 & \\
\hline 15.07.2005 00:00 & $23.07 .200500: 00$ & -4.74 & -11.53 & $\mathrm{x}$ \\
\hline $23.07 .200500: 00$ & 09.08.2005 00:00 & -4.51 & -0.82 & $\mathrm{x}$ \\
\hline $09.08 .200500: 00$ & $15.08 .200500: 00$ & - & - & \\
\hline $15.08 .200500: 00$ & $22.08 .200500: 00$ & -4.27 & 1.45 & \\
\hline $22.08 .200500: 00$ & $29.08 .200500: 00$ & -5.44 & 0.38 & \\
\hline $29.08 .200500: 00$ & $05.09 .200500: 00$ & -4.76 & 0.14 & \\
\hline 05.09.2005 00:00 & 12.09.2005 00:00 & -4.82 & 0.95 & \\
\hline 12.09.2005 00:00 & 19.09.2005 00:00 & -5.03 & 1.51 & \\
\hline 19.09.2005 00:00 & 17.10.2005 00:00 & -5.26 & 1.39 & $\mathrm{x}$ \\
\hline
\end{tabular}




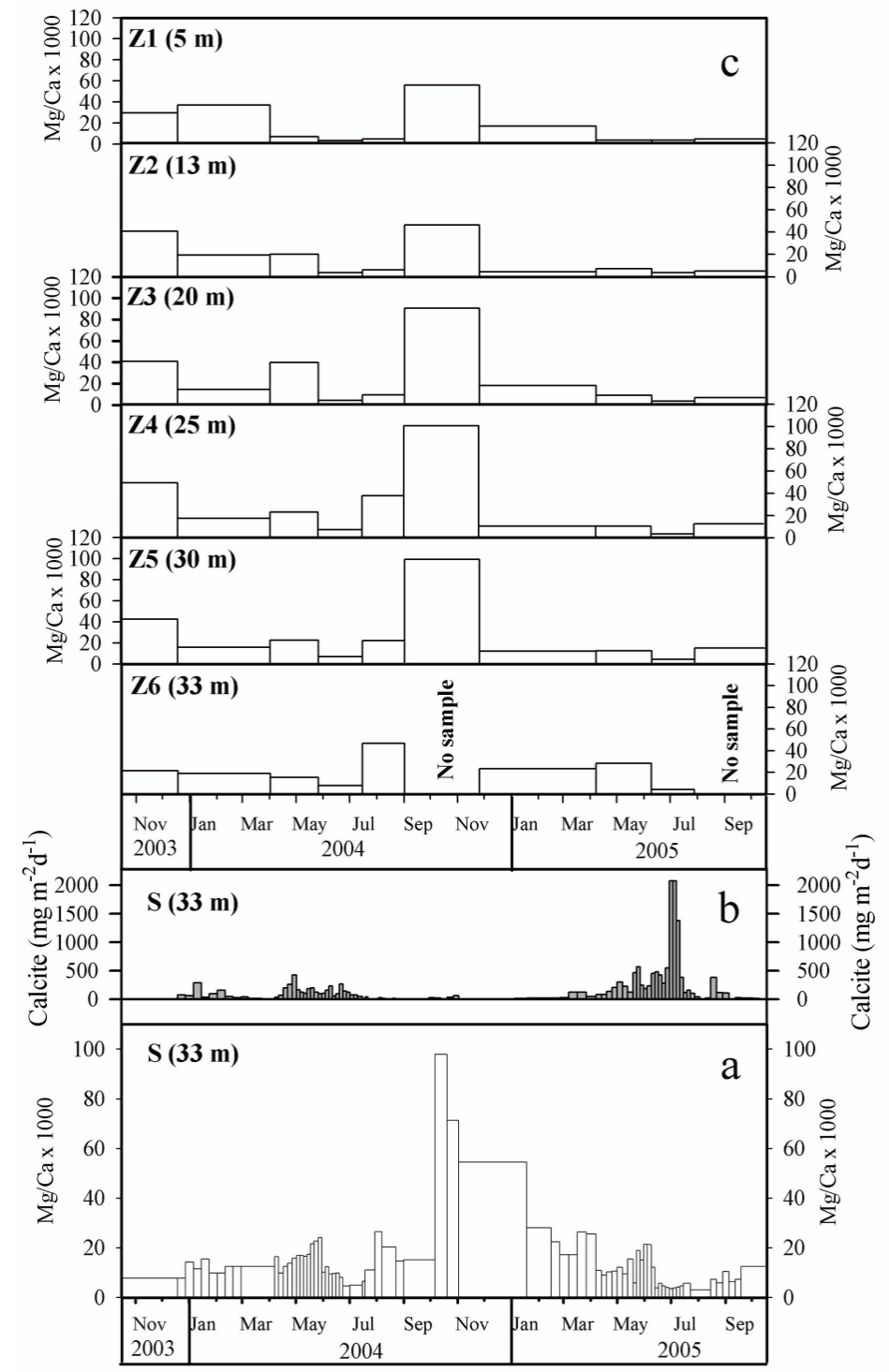

Fig. 5. Mg:Ca ratios (multiplied with 1000) of carbonates in the sequential sediment trap (S-trap, panel a) and in the cylindrical traps (Z-traps, panel c) at depths of 5, 13, 20, 25, 30 and $33 \mathrm{~m}$ from October 2003 until October 2005. Calcite flux (33 m) in the S-trap is shown for comparison (panel b).

Expected equilibrium oxygen isotopic compositions (Fig. 4c) were lowest for summer 2004 (June to August) with values between -2.5 and $-3.0 \%$ similar to the same period in 2005 (-2.6 to $-3.2 \%$ ). Positive values were calculated between November 2003 and March 2004 (up to $0.7 \%$ ) and between November 2004 and March 2005 (up to $0.96 \%$ ).

\subsection{Magnesium to calcium ratio}

Magnesium to calcium ratios $(\mathrm{Mg}: \mathrm{Ca} \times 1000)$ of cylindrical traps (Z-traps) showed changes mainly during summer months and in autumn (Fig. 5). Lowest ratios were found during the fourth interval (end of May to middle of July 2004) with 7.7 in Z6 and 3.4 in Z1 and also during approximately the same period in 2005 (3.5 to 4.0). Highest ratios occurred from September until
November 2004 with values around 100 in the deep trap (Z5) and around 50 in the two uppermost traps.

The Mg:Ca record of calcites in the S-trap showed several maxima. In general, $\mathrm{Mg}: \mathrm{Ca}$ ratios are in the range between 3 and 28. Exceptionally high ratios (around 100) were recorded during October through December 2004. For both 2004 and 2005, Mg:Ca ratios increased from early April to late May and decreased from there to the end of June. Ratios measured for samples from November 2004 until March 2005 were above the mean.

\subsection{Strontium to calcium ratio}

Strontium to calcium ratios $(\mathrm{Sr}: \mathrm{Ca} \times 1000)$ in Ztraps varied between 3 and 10.1 (Fig. 6). Similar to $\mathrm{Mg}: \mathrm{Ca}$ ratios, values of $\mathrm{Sr}$ :Ca were lowest during early 


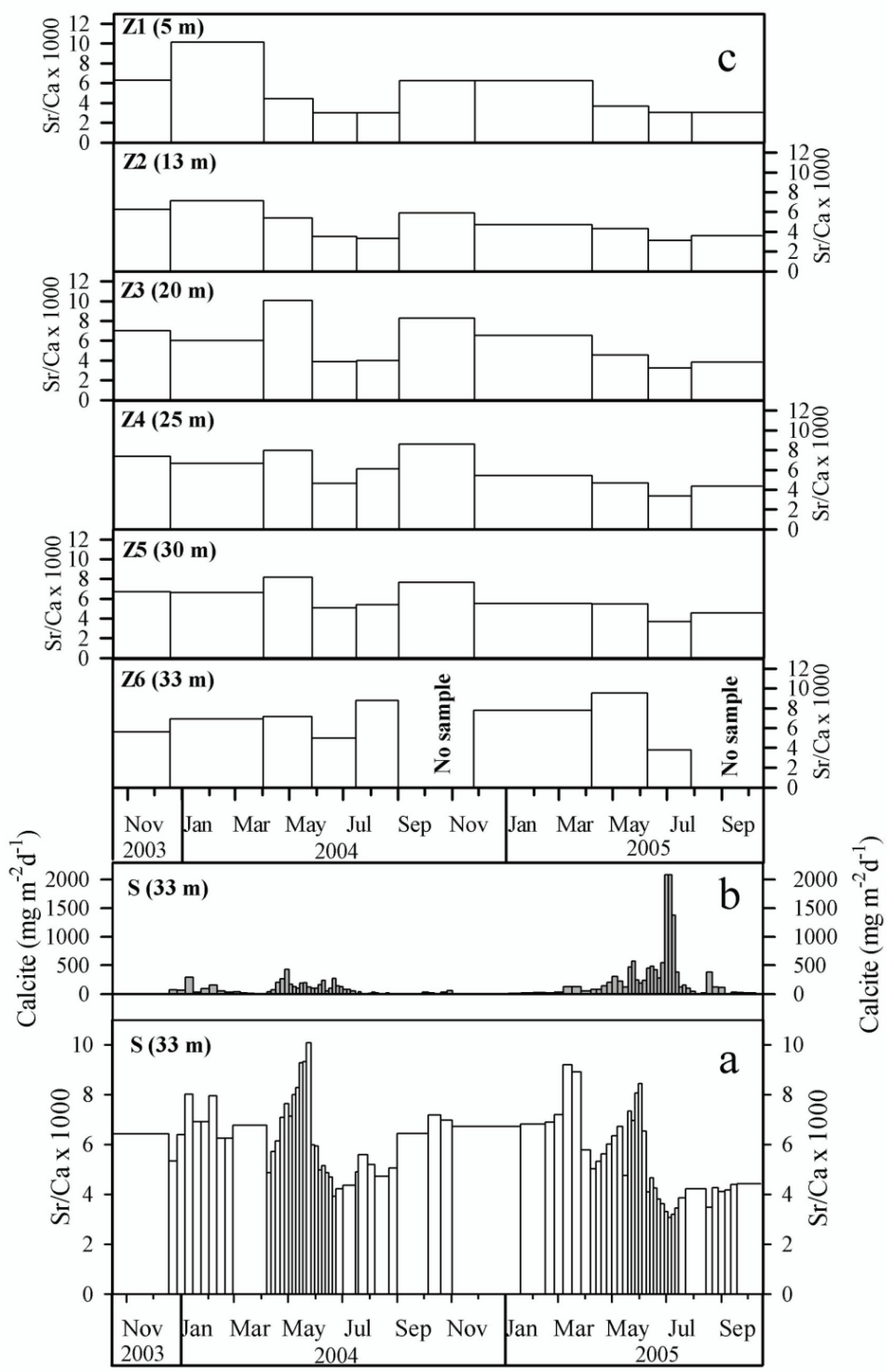

Fig. 6. Sr:Ca ratios (multiplied with 1000) of carbonates in the sequential sediment trap (S-trap, panel a) and of the cylindrical traps (Z-traps, panel c) at depths of 5, 13, 20, 25, 30 and $33 \mathrm{~m}$ from October 2003 until October 2005. Calcite flux (33 m) in the S-trap is shown for comparison (panel b).

summer (June) and highest in April/May of both years as well as from September to November 2004 with the exception of Z1 $(5 \mathrm{~m})$. There were no distinct gradients from the lake bottom to the surface, except for summer intervals (June) where ratios increased with depth.

$\mathrm{Sr}: \mathrm{Ca}$ ratios of the S-trap samples showed a similar development like $\mathrm{Mg}: \mathrm{Ca}$ ratios during summer. After relatively constant values between 6 and 7 , ratios decreased to 4 for a very short time and then increased steadily from March to May 2004 reaching the value of 10. At the end of May the values decreased to 4 and after July a second increase was observed. During autumn 2004 and winter 2004/2005 $\mathrm{Sr}: \mathrm{Ca}$ ratios increased to 7 and later to 9 . In spring $2005 \mathrm{Sr}: \mathrm{Ca}$ ratios were lower than 5 but increased steadily to 8.5 at the end of May. Similar to 2004, values decreased to $\sim 3$ at the beginning of July. A second very small increase thereafter was also detected at the end of July 2005.

\section{DISCUSSION}

\subsection{Stable isotopes of lake water}

In general, in temperate regions oxygen isotopes of all continental waters reflect the isotopic composition of catchment precipitation (Gat 1981a) and groundwater values correspond to precipitation values during times of maximum infiltration (Gat 1981b; Fischer 1996). $\delta^{18} \mathrm{O}_{\text {water }}$ of Sacrower See surface water was enriched in ${ }^{18} \mathrm{O}$ by evaporation in late summer $(-1.3 \%$ ) relative to the rest of the year $(-2.5 \%$; Fig. 2$)$. The maximum dif- 
ference is $1.2 \%$. In contrast, the groundwater is much more depleted in ${ }^{18} \mathrm{O}(-8.8$ to $-8.6 \%)$ than the lake water and about $1 \%$ more depleted than the long term weighted average isotopic composition of precipitation from the GNIP-station in Berlin (-7.8\%). Compared to the isotopic composition of precipitation and groundwater the water of the River Havel is less depleted in ${ }^{18} \mathrm{O}$ with -5 to $-6 \%$ (Massmann et al. 2004) but is still about 3\%o lower than the lake water. Hence, today neither groundwater nor precipitation controls the ${ }^{18} \mathrm{O}$ enrichment of the lake water. Between late summer of 2003 and 2004 there is no significant difference in surface water oxygen isotope ratios whereas values for 2005 are about $0.4 \%$ more negative than those of 2004 .

The River Havel has not contributed to the observed lake water isotopic composition since its connection to Sacrower See closed in 1986. All other tributaries from the catchment are small. The only inflow from the northwestern Groß Glienicker See through a pipe amounts to max. 1.3 million $\mathrm{m}^{3} \mathrm{a}^{-1}$. With a water volume of $0.0151 \mathrm{~km}^{3}$ the lake's water residence time is around 12 years (Rümmler et al. 1997). Potentially, lake water isotopic composition, which is different from long-term precipitation and groundwater values, is a result of long term isotopic enrichment by summer evaporation. It is conceivable that the drainage of Groß Glienicker See decreased in the last years, resulting in even longer residence times which would allow an enrichment of ${ }^{18} \mathrm{O}$ by several per mill. Smaller ${ }^{18} \mathrm{O}$ enrichment values have also been reported from other European lakes. Von Grafenstein et al. (1992) recorded discrepancies between oxygen isotopic composition of precipitation to lake water of $-1 \%$ in Ammersee and $-3 \%$ in Starnberger See, both southern Germany (residence time 2.7 and 21 years, respectively). Eicher (1979) found a $2 \%{ }^{18} \mathrm{O}$ enrichment in the lake water versus groundwater in Gerzensee, Switzerland (residence time 4 years). Nevertheless, the enrichment of $6 \%$ in Sacrower See is comparatively large and not understood.

\subsection{Stable isotopes of carbonates}

$\delta^{18} \mathrm{O}_{\mathrm{ca}}$ and $\delta^{13} \mathrm{C}$ of the S-trap and the lower Z-traps show a similar development with quite negative values in winter caused by resuspended authigenic material from the lake shore which did not include allochthonous carbonates and more positive values from July to October. Isotope values of calcites deposited in the surface traps in spring and summer are more positive than those of the deep water traps. This might be the result of time lags between precipitation of calcite in the epilimnion and its final deposition on the lake bottom (Bluszcz et al. 2008). It is supposed that this may also be a result of different grain sizes of the calcites but has not been investigated. However, different processes may be at work. After times of maximum production and subsequent decomposition, low calcite saturation and anoxic conditions prevailed in the bottom waters. Partial dissolution of calcites occurred while settling through the hypolimnetic water column and only a minor fraction of total calcite from the surface waters reached the lake bottom (Bluszcz et al. 2008; c.f. Ohlendorf \& Sturm 2001). This could have influenced the isotopic composition of the calcites deposited. During winter oxygen and carbon isotope values were relatively negative (Fig. $4 a, b)$ with a slightly more positive trend towards the deeper traps (Fig. 3a, b, intervals 2 and 7, except carbon in 2005). Since there was no calcite precipitation during these times, carbonates caught in the traps must be part of resuspended sediment. We hypothesize that very negative isotopic values in the traps during winter and early spring are the result of resuspension and particle dissolution. Little is known about the isotopic composition of lacustrine calcites affected by dissolution. Hitherto, there is no discussion on distinct changes of oxygen or carbon isotopic composition of lacustrine calcite during partial dissolution in literature. Skidmore et al. (2004) showed in laboratory dissolution tests that $\delta^{13} \mathrm{C}$ DIC produced during hydrolysis of $\mathrm{CaCO}_{3}$ was $7.8 \%$ lower than the bulk carbonate. Thus, carbonates affected by dissolution should have more positive $\delta^{13} \mathrm{C}$ and slightly more positive $\delta^{18} \mathrm{O}_{\text {ca }}$ values than expected. This would be consistent with the results of sediment trap samples (Z-traps), where isotopic values increased with increasing depth which might be a result of increasing dissolution during autumn and winter.

Autumn and winter samples of 2003/2004 probably contain resuspended material from the shore line and from the two other lake basins (Bluszcz et al. 2008). Hence, their $\delta^{18} \mathrm{O}_{\text {ca }}$ and $\delta^{13} \mathrm{C}$ values are influenced by admixtures of calcite that was precipitated in the previous year mainly from littoral areas. As Sacrower See consists of three basins, where sediments are also laminated (unpublished data), resuspension from the profundal of these basins can be widely excluded. The second autumn and winter period (September 2004 until February 2005) was dominated by resuspension events, mixis and low calcite fluxes, too. During March 2005 a first peak of biological production occurs (Fig. 7a). However, these samples probably are mixed with sediment from resuspension (Bluszcz et al. 2008) because stratification was not yet established. High contents of biogenic silica suggest that a diatom bloom occurred.

The pronounced mixis of the water body in early spring 2004 (mid-April) presumably resulted in the reestablishment of a common carbon isotope value of the dissolved inorganic carbon (DIC) pool for the entire lake. $\delta^{13} \mathrm{C}$ values of aquatic organic matter normally are in a range of -20 to $-30 \%$ (Pearson \& Coplen 1978). During decomposition the large pool of ${ }^{12} \mathrm{C}$ is released into hypolimnic waters and this lower $\delta^{13} \mathrm{C}$ water is mixed with surface waters due to spring overturn. With increasing admixture of depleted bottom waters, precipitating carbonates in surface waters will become 


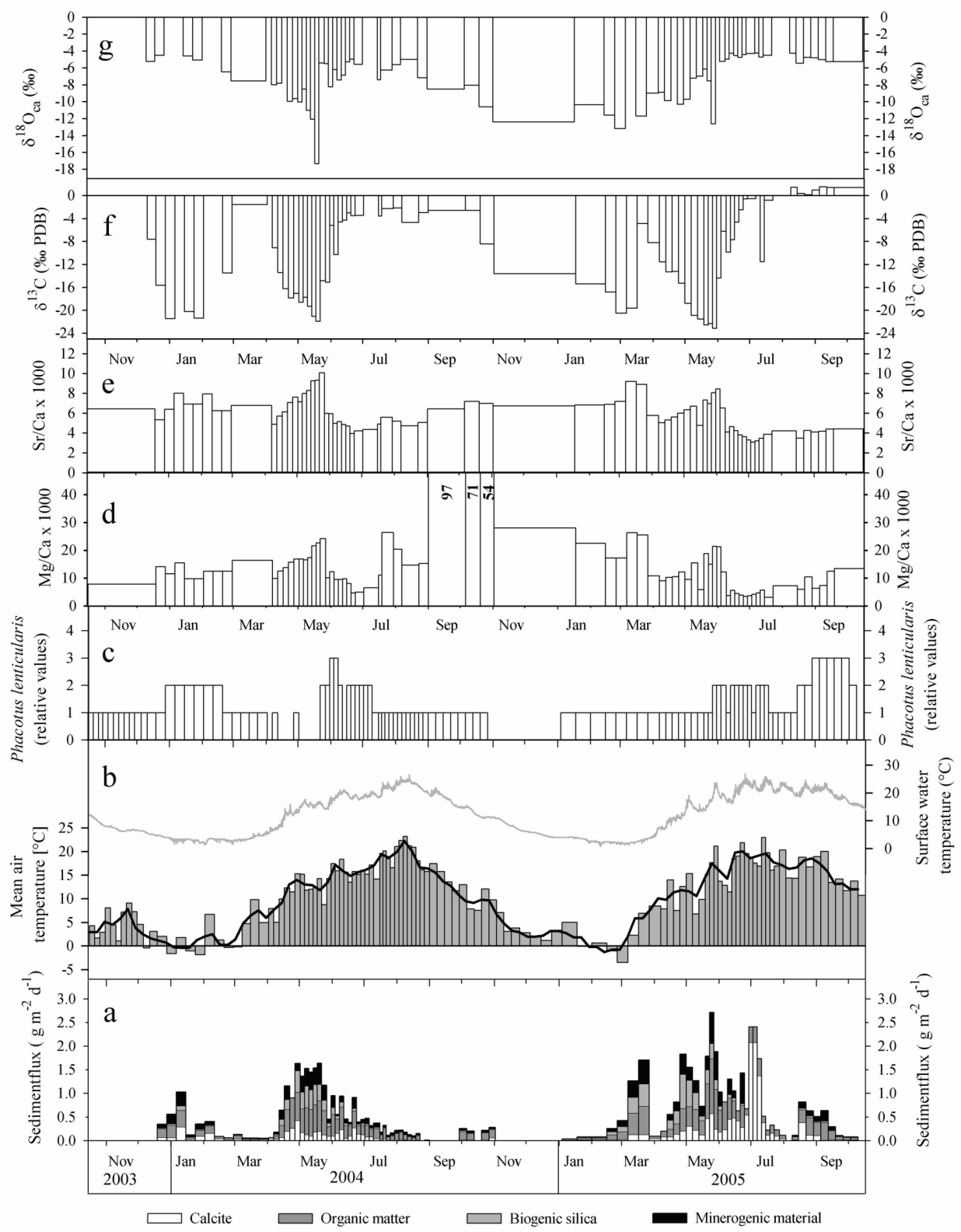

Fig. 7. Interpretative presentation of sediment fluxes of the sequential sediment trap (panel a), which are split into their constituents calcite, organic matter, biogenic silica and inorganic matter. Mean air temperature and surface water temperature (panel b), amounts of Phacotus lenticularis (panel c), classification for Phacotus from 0 to 4 (0:absent, 1:<5\% rare; 2:5-25\%, common; 3: $>25 \%$, abundant; 4: $>50 \%$, dominant), $\mathrm{Mg}: \mathrm{Ca}$ and $\mathrm{Sr}: \mathrm{Ca}$ ratios (panels $\mathbf{d}$ and $\mathbf{e}$ ) and $\delta^{13} \mathrm{C}$ and $\delta^{18} \mathrm{O}$ of calcite (panels $\mathbf{f}$ and $\mathbf{g}$ ) of the sequential sediment trap (S-trap). Note that the width of the bars is equivalent to the length of the exposure-intervals of individual sediment trap samples.

more depleted in ${ }^{13} \mathrm{C}$ following the trend in the inorganic carbon pool. During the following early phase of stratification in May, the consumption of $\mathrm{CO}_{2}$ by aquatic plants and algae would lead to an enhanced transfer of atmospheric $\mathrm{CO}_{2}$ into the surface waters (Chondrogianni 1992). Together with photosynthesis which preferentially takes ${ }^{12} \mathrm{C}$ from DIC, leaving it enriched in ${ }^{13} \mathrm{C}$, carbonates preciptated during these times show more positive carbon isotope values compared to summer.
In the early phase of active photosynthesis (April to May), calcite formation may be inhibited by high concentrations of phosphate (Fig. 4c; Niessen \& Sturm 1987; Teranes et al. 1999a; Bluszcz et al. 2008). After the decrease of phosphate concentration due to increased primary production, calcite crystals form very rapidly because of the high degree of supersaturation caused by phosphate-mediated inhibition. Fast crystal growth is dominated by kinetic fractionation, starts in isotopic disequilibrium with the ambient water, and 
leads to a preferred incorporation of the lighter isotopes ${ }^{12} \mathrm{C}$ and ${ }^{16} \mathrm{O}$ into the calcite lattice (Pearson \& Coplen 1978) which in turn causes the observed low isotopic values. Together with the time lags estimated by comparison of the calcite fluxes for different traps between epilimnic calcite precipitation and deposition, as well as hypolimnetic dissolution, a stepwise shift towards more negative $\delta^{13} \mathrm{C}$ values is conceivable. The simultaneous increase of the biological production with its preferred uptake of ${ }^{12} \mathrm{C}$ causes an increase in ${ }^{13} \mathrm{C}$ of the DIC of the surface waters. Growing stability of lake water stratification prevents the mixing with ${ }^{12} \mathrm{C}$ released from deep water decomposition processes. With decreasing calcite supersaturation (c.f. Bluszcz et al. 2008) of the surface waters, calcite precipitation slows down which leads to carbonate precipitation near isotopic equilibrium. Together, these effects lead again to higher isotope values of cabonates precipitating later in the season.

In summer $2005, \delta^{13} \mathrm{C}$ values decreased again because large quantities of ${ }^{12} \mathrm{C}$ were released during decomposition and were made available for uptake by algal production. We assume that the DIC-pool was enriched in ${ }^{12} \mathrm{C}$ and the fast calcite precipitation after uptake of the crystal growth inhibitor phosphate, leads to more negative $\delta^{13} \mathrm{C}$ values in the carbonates. From June until the beginning of July $2005 \delta^{13} \mathrm{C}$ values increased because of the enhanced incorporation of ${ }^{12} \mathrm{C}$ in algal organic matter during epilimnic primary production. The increase is about 3.5\% larger than in the previous year which is probably due to a higher production and higher total and calcite fluxes in 2005 compared to 2004 (Fig. 7a, f). At the end of July $\delta^{13} \mathrm{C}$ decreases again for a short time period caused by maximum calcite precipitation but increases again to positive values of about 1.9\%o. In August and September 2005 when high amounts of ${ }^{12} \mathrm{C}$ have been removed from the surface water by primary production, the DIC is comparably enriched in ${ }^{13} \mathrm{C}$. Hence, carbonates that precipitate at this time record more positive $\delta^{13} \mathrm{C}$ values. The oxygen isotopic composition during this period was not the same as in 2004. The observed decrease of $\delta^{18} \mathrm{O}_{\text {ca }}$ values in spring/summer 2005 was less pronounced than in 2004. During June and July $\delta^{18} \mathrm{O}$ values were more or less constant and afterwards decreased slightly with a peak of calcite fluxes occurring in August which may have been caused by a period of production.

From end of March through May $2004 \delta^{18} \mathrm{O}$ and $\delta^{13} \mathrm{C}$ became more negative. This is in concert with lake water stratification, the main phase of biological production and hence calcite precipitation. Calcite flux as well as organic matter flux recorded by the S-trap during both years of investigation differed significantly. In spring and summer 2005, calcite precipitation began early, its flux was high $\left(52 \mathrm{~g} \mathrm{~m}^{-2}\right)$ and had several distinct peaks. In contrast during the same time period in 2004 calcite flux was lower $\left(15.1 \mathrm{~g} \mathrm{~m}^{-2}\right)$ and more constant (Bluszcz et al. 2008).
Similar to the studies of Schelske \& Hodell (1991) and Hodell et al. (1998) at Lake Ontario, calcite accumulation and $\delta^{13} \mathrm{C}$ of carbonates at Sacrower See probably are controlled by interannual variability of the onset of lake water stratification. This in turn is linked to climate processes (e.g., air and surface water temperatures). It is assumed that regional climate patterns influence water column stratification (Bluszcz et al. 2008) and hence, the onset and characteristics of primary production, calcite precipitation rates and consequently the isotopic composition of the lake internal carbonates. The comparison of 2004 with 2005 clearly demonstrates that an earlier onset and more stable stratification, as indicated by surface water temperature, causes higher fluxes and more positive carbon and oxygen values in 2005 (Fig.7a, b, f, g). Besides biochemically precipitated calcite, the calcifying green algae Phacotus lenticularis which occurs in mass blooms in summer may influence the $\delta^{18} \mathrm{O}_{\mathrm{ca}}$ and $\delta^{13} \mathrm{C}$ value of the total calcite (Fig. 7c,f,g). Phacotus amounts up to $50 \%$ of total calcite during summer 2005 and up to one third of the annual calcite flux (Bluszcz et al. 2008). It is conceivable that so called vital effects similar to those of other calcifying species like ostracodes (Chivas et al. 1993) result in a species specific fractionation and thus may lead to more negative $\delta^{18} \mathrm{O}_{\text {ca }}$ and more positive $\delta^{13} \mathrm{C}$ values. In the case of Sacrower See decreasing productivity is accompanied by decreasing calcite precipitation and increasing total Phacotus content. These conditions occur during summer of both years. Fronval et al. (1995) and Teranes et al. (1999a, b) state that trophic conditions might influence isotope ratios. Our results support this theory and in addition demonstrate that the delayed precipitation of calcite also causes positive carbon isotope ratios. Concerning oxygen isotope ratios more negative values beyond equilibrium were observed.

\subsection{Reasons for oxygen isotope disequilibrium}

During times of low calcite formation in the surface waters, the discrepancies between isotopic composition of resuspended or partially etched calcite and calculated $\delta^{18} \mathrm{O}_{\text {ca }}$ values might be expected. There were differences between measured and expected $\delta^{18} \mathrm{O}_{\mathrm{ca}}$ values during the time period of calcite precipitation induced by photosynthetic activity. The differences were largest during early spring and smallest in summer (1.2 to 5.7\%); (Fig. $8 \mathrm{a}, \mathrm{b}$ ). The difference in spring and summer implies that calcite did not precipitate in equilibrium with its ambient water. The disequilibrium is larger in 2004 than in 2005. Oxygen isotope values are outside of the calculated isotopic equilibrium. In 2005 a trend from nearly equilibrium values in summer to more depleted values in winter (Fig. 8c, d) was detected. Spring values were influenced by crystal growth inhibition caused by high phosphate contents followed by fast crystal growth which caused isotopic disequilibrium. Thus, like in 

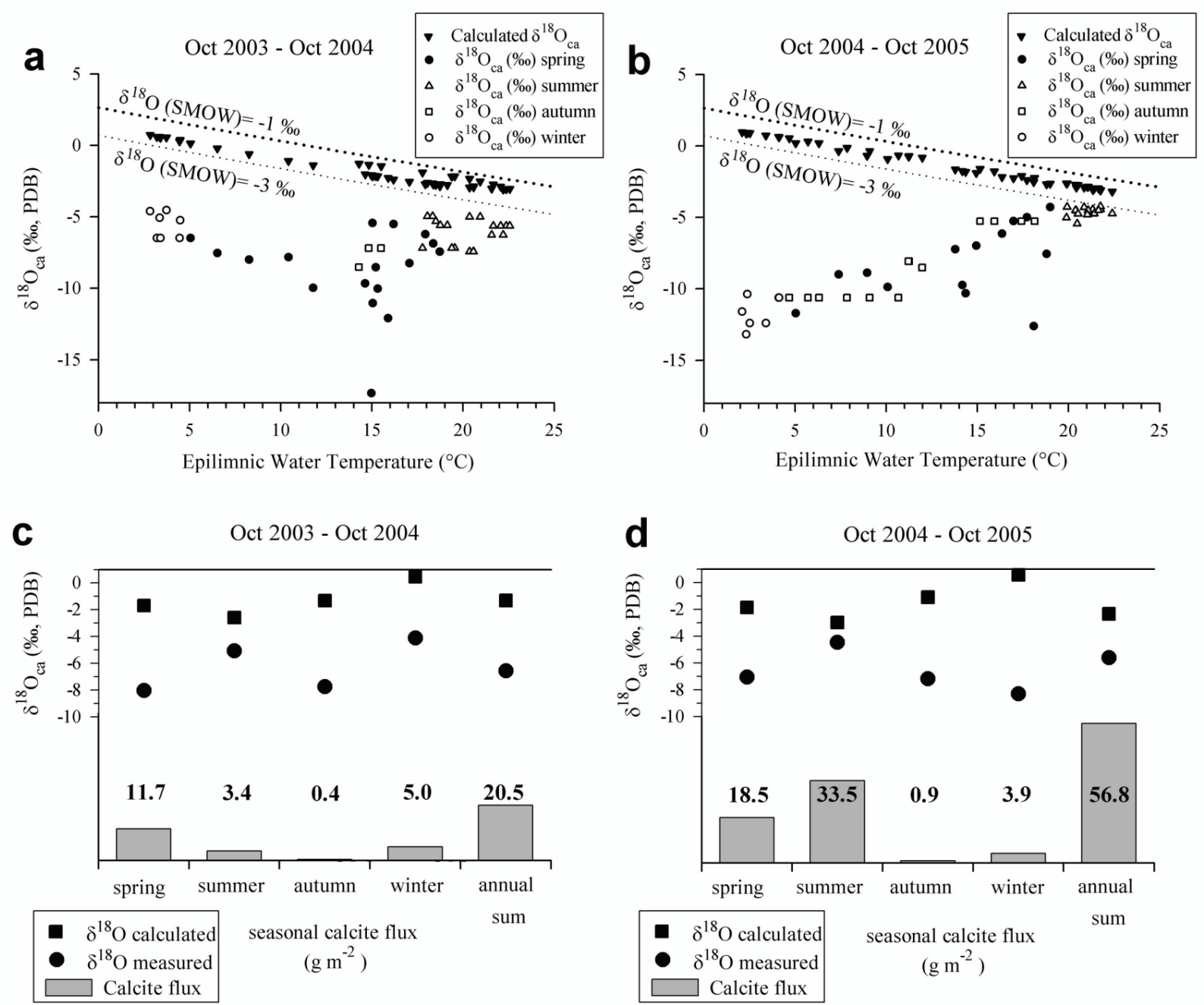

Fig. 8. Comparison of measured and calculated $\delta^{18} \mathrm{O}$ of seasonal precipitated carbonates versus measured surface water temperatures $(0-5 \mathrm{~m})$. Dashed lines limit boundaries for isotopic equilibrium based on the approximate minimum (-1\%) and maximum (-3\% $)$ boundaries of $\delta^{18} \mathrm{O}$ values of the lake water $(\mathbf{a}, \mathbf{b})$ and compiled oxygen isotope values for individual seasons and annual values using calcite accumulation rates and measured $\delta^{18} \mathrm{O}$ values from the sediment trap samples for October 2003 until October 2004 (c) and for October 2004 until October 2005 (d).

other lakes (Fronval et al. 1995; Teranes et al. 1999a, b), high eutrophication limits the use of oxygen isotopes as a climate or environmental proxy. In Sacrower See isotope values are the result of a mixture of two carbonate species (bioinduced calcite/phacotus shells).

\subsection{Element ratios}

Element ratios showed opposite trends to oxygen isotopic values (Fig. 7d, e). Strontium to calcium ratios and $\delta^{18} \mathrm{O}_{\text {ca }}$ are negatively correlated. In spring and summer (April to June) of 2004 values show a higher negative correlation $(r=-0.865, p<0.05, \mathrm{n}=19)$ than in $2005(r$ $=-0.697, p<0.05, \mathrm{n}=16$; see Fig. 9a, b). Magnesium to calcium ratios also show higher negative correlation with $\delta^{18} \mathrm{O}_{\mathrm{cc}}$ in spring/summer $2004(r=-0.89, p<0.05, \mathrm{n}=$ 19) than in $2005(r=-0.641, p<0.05, \mathrm{n}=16$; see Fig. $9 \mathrm{c}, \mathrm{d})$. There is almost no correlation between surface water temperatures and element ratios $(r<-0.1)$. Calcites in Sacrower See are low-Mg-calcites (Bluszcz et al. 2008) We assume that elevated $\mathrm{Mg}: \mathrm{Ca}$ and $\mathrm{Sr}: \mathrm{Ca}$ ratios of carbonates during spring are the result of the fast precipitation with kinetically controlled incorporation of $\mathrm{Mg}$ and $\mathrm{Sr}$, whereas during slow calcite precipitation equilibrium process dominates and $\mathrm{Ca}$ is incorporated preferentially. Thus, the occurrence of phosphate as the inhibitor of calcite precipitation influences the amounts of $\mathrm{Mg}$ and $\mathrm{Sr}$ in the carbonates of Sacrower See. When photosynthetic activity and calcite precipitation continues and water column stratification stabilizes, $\mathrm{Mg}$ which is also an important nutrient for algae (Wetzel 2001) will be removed from the water causing average $\mathrm{Mg}: \mathrm{Ca}$ ratios. Sr incorporation into calcite may occur with analogous mechanism. In most cases $\mathrm{Mg}: \mathrm{Ca}$ and $\mathrm{Sr}: \mathrm{Ca}$ can be used to track the salinity of a lake if it is a closed basin system (Lemcke \& Sturm 1997). 

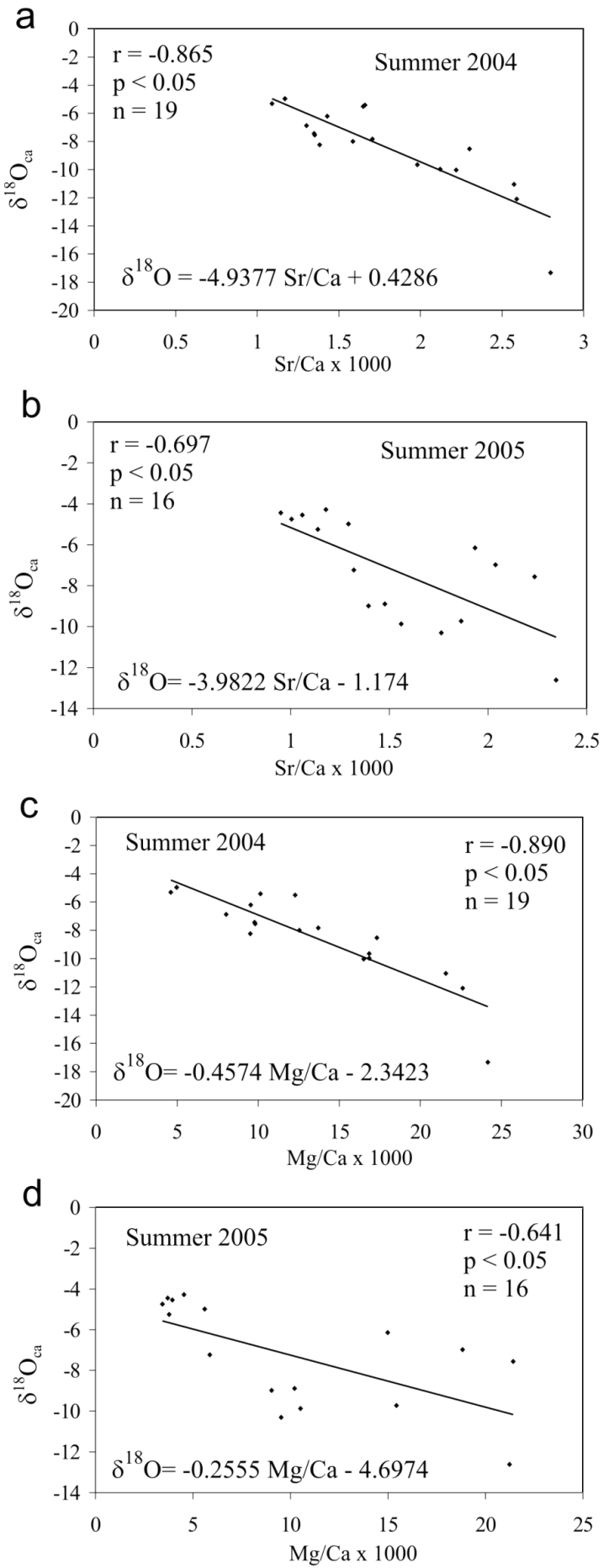

Fig. 9. Correlation of $\delta^{18} \mathrm{O}$ values and $\mathrm{Sr}$ :Ca ratios $(\times 1000)$ of carbonates from the sediment trap samples for summer 2004 (panel a) and summer 2005 (panel b). Correlation of $\delta^{18} \mathrm{O}$ values and $\mathrm{Mg}$ :Ca ratios $(\times 1000)$ of carbonates from sediment trap samples for summer 2004 (panel c) and summer 2005 (panel d).

In general, $\mathrm{Mg}: \mathrm{Ca}$ of the lake surface water is several times higher than recorded in the carbonates, so that $\mathrm{Mg}: \mathrm{Ca}$ of the carbonates records only relative changes in Mg:Ca ratios of the lake water (Müller et al. 1972). Generally, the investigated element ratios are also influenced by the rate of photosynthetic activity and thus by the rate of calcite precipitation but to a still unknown degree. High calcite precipitation rates favour higher $\mathrm{Mg}: \mathrm{Ca}$ and $\mathrm{Sr}: \mathrm{Ca}$ ratios, especially in 2005 where all calcite flux peaks are mirrored in more or less distinct changes of $\mathrm{Sr}: \mathrm{Ca}$ and to a lesser extent in $\mathrm{Mg}:$ Ca ratios.

As dissolution processes influence the precipitated calcites during deposition, $\mathrm{Mg}: \mathrm{Ca}$ and $\mathrm{Sr}$ Ca ratios may be altered significantly. During spring, $\mathrm{Mg}: \mathrm{Ca}$ and $\mathrm{Sr}: \mathrm{Ca}$ ratios of carbonates in the surface traps (Z1) are a few times lower than those of carbonates trapped near the bottom (Z6). Autumn and winter values are results of resuspension processes. During the main occurrence of Phacotus in late spring and summer element ratios were low, except during September 2005 when average ratios were observed. Thus, Phacotus may also have an influence on element ratios.

\section{CONCLUSIONS}

Oxygen and carbon isotopes as well as element ratios of lacustrine carbonates show a high interannual variability forced by lake internal and climatic parameters. With the help of high-resolution sediment trap data from different water depths, water chemistry, physical water parameters and climate data, we were able to detect seasonal responses and time lags between precipitation and deposition of calcite particles and their oxygen and carbon isotopic as well as their element composition. In particular the following conclusions can be drawn: (1) Similar to other studies (Fronval et al. 1995; Teranes et al. 1999a) eutrophication marked by high total phosphate concentrations in the water column inhibits calcite precipitation in early spring and leads to an abrupt calcite precipitation in late spring which causes oxygen isotope fractionation in which the degree of disequilibrium is equivalent to the level of eutrophication. (2) Due to $\mathrm{CO}_{2}$ release during decomposition of organic matter in the water column, calcites are partly dissolved which results in changes of their isotopic signature to slightly more positive values. (3) Element ratios show a signal which is consistent with the stable isotope results in most of the observed time period. $\mathrm{Sr}: \mathrm{Ca}$ and $\mathrm{Mg}: \mathrm{Ca}$ ratios mirror the $\delta^{13} \mathrm{C}$ and to a lesser extent the $\delta^{18} \mathrm{O}_{\mathrm{ca}}$ signal during the main phase of calcize precipitation in spring. We hypothesise that salinity controls the amount of $\mathrm{Mg}$ and $\mathrm{Sr}$ in calcite crystals. Therefore sediments should record the degree of salinity in surface waters. Similar to stable isotope ratios, element concentrations in calcite crystals were altered by resuspension and dissolution processes during deposition. (4) The fractionation of isotopes in the calcite shells of the calcified green algae Phacotus lenticularis may be different from those of the authigenic calcite ("vital effects"). This in turn would result in an altera- 
tion of the isotopic signal determined from total inorganic carbon (authigenic calcite and Phacotus shells). Our results show a coincidence between the occurrence of Phacotus and slightly more positive $\delta^{18} \mathrm{O}_{\mathrm{ca}}$ as well as more positive $\delta^{13} \mathrm{C}$ values. Low $\mathrm{Sr}: \mathrm{Ca}$ and $\mathrm{Mg}$ :Ca ratios of calcite were observed during the main occurrence of Phacotus between end of May and July. (5) Onset and stability of lake water stratification during spring and summer influences the biological production, and hence also the beginning of calcite precipitation and sediment flux which in turn affects stable isotope ratios. Thus, stable isotope ratios of carbon and oxygen possibly might be a proxy for the onset and stability of lake water stratification in Sacrower See. As stratification is mainly controlled by air temperature and insolation, these parameters also influence stable isotopes and element ratios.

Concerning oxygen and carbon isotopic composition of carbonates in eutrophic lake systems, interpretation of these values should be undertaken with care because of the possible disequilibrium. It is essential for the interpretation of the paleorecord that the role of Phacotus and its isotopic fractionation is known. Hitherto we were not able to isolate phacotus shells from the total carbonate to ascertain its isotopic composition. For further studies it would also be of great value to determine the carbon isotopic composition of the dissolved inorganic carbon (DIC) fraction as well as $\mathrm{Mg}$ and $\mathrm{Sr}$ concentrations of the lake water for comparison as at the moment we only can presume these values.

\section{ACKNOWLEDGMENTS}

We thank Dirk Enters, Torsten Haberzettl, Britta Lüder, Stephanie Kastner, Michael Fey and Christian Korr for help during fieldwork. Werner Laumer, Sabine Stahl, Ilsetraut Stölting and Michael Kriews are acknowledged for assistance with geochemical analyses. We are much obliged to thank Herbert Ebel, Uwe Brämick, Frank Rümmler and Steffen Zienert from the Institut für Binnenfischerei Potsdam for their support during fieldwork and for providing their local infrastructure. Willibald Stichler from the Institute of Groundwater Ecology of the National Research Centre for Environment and Health in Neuherberg, Germany for providing the isotope data of the GNIP-station (GNIP: Global Network for Isotopes in Precipitation) in Berlin. Hermann Oesterle and Friedrich-Wilhelm Gerstengarbe provided the data recorded at the meteorological station at Potsdam-Telegrafenberg. This study was supported by grant DFG Zo 102/4-1 of the German Science Foundation and the Central Research Supply (Zentrale Forschungsförderung) of the University of Bremen (08/141/2).

\section{REFERENCES}

Anadón, P., R. Utrilla, A. Vázquez, M. Martin-Rubio, J. Rodriguez-Lázaro \& F. Robles. (2009). Paleoenvironmental evolution of the Pliocene Villarroya Lake, northern Spain, from stable isotopes and trace element geochemistry of ostracodes and molluscs. J. Paleolimnol., (in press), doi:10.1007/s10933-007-9121-2

Beck, J.W., R.L. Edwards, E. Ito, F.W. Taylor, J. Recy, F. Rougerie, P.Joannot \& C. Henin. 1992. Sea-surface temperature from coral skeletal strontium/calcium ratios. Science, 257: 644-647.

Bluszcz, P., E. Kirilova, A.F. Lotter, C. Ohlendorf \& B. Zolitschka. 2008. Global radiation and onset of stratification as forcing factors of seasonal carbonate and organic matter flux dynamics in a hypertrophic hardwater lake (Sacrower See, northeastern Germany). Aquat. Geochem., doi:10.1007/s10498-008-9026-3

Chivas, A.R., P. De Deckker, J.A. Cali, A. Chapman, E. Kiss \& J.M.G. Shelley. 1993. Coupled stable-isotope and traceelement measurements of lacustrine carbonates as paleoclimatic indicators. In: P.K. Swart, K.C. Lohmann, J. McKenzie \& S. Savin (Eds), Climate change in continental isotopic records. Geophysical Monograph. Amercian Geophysical Union, Geophysical Monograph: 113-121.

Chondrogianni, C. 1992. Stabile Kohlenstoff-Isotope in hochproduktiven Litoralflächen des Bodensees - Indikation für die Kopplung physikalischer, biologischer und geochemischer Prozesse im Kohlenstoff-Kreislauf. Ph.D. thesis. Rupprecht-Karls-Universität Heidelberg.

Coplen, T.B., C. Kendall \& J. Hopple. 1983. Comparison of stable isotope reference samples. Nature, 302: 236-238.

Crausbay, S.D., J.M. Russell \& D.W. Schnurrenberger. 2006. A ca. 800-year lithologic record of drought from sub-annually laminated sediments, East Java. J. Paleolimnol., 35 : 641-659. doi:10.1007/s10933-005-4440-7

Dwyer, G.S., T.M. Cronin \& P.A. Baker. 2002. Trace elements in marine ostracodes. In: J.A. Holmes \& A.R. Chivas (Eds), The Ostracoda - Applications in quaternary research. AGU: 205-225.

Eicher, U. 1979. Die ${ }^{18} \mathrm{O} /{ }^{16} \mathrm{O}$ und ${ }^{13} \mathrm{C} /{ }^{12} \mathrm{C}$-Isotopenverhältnisse in spätglazialen Suesswasserkarbonaten und ihr Zusammenhang mit den Ergebnissen zur Pollenanalyse. Ph.D. thesis. Universität Berlin.

Fairchild, I.J. , C.L. Smith, A. Baker, L. Fuller, C. Spötl, D. Mattey, F. McDermott \& E.I.M.F. 2006. Modification and preservation of environmental signals in speleothems. Earth Sci. Rev., 75: 105-153. doi:10.1016/j.earscirev.2005. 08.003.

Filippi, M.L., P. Lambert, J.C. Hunziker \& B. Kübler. 1998. Monitoring detrial input and resuspension effects on sediment trap material using mineralogy and stable isotopes $\left(\delta^{18} \mathrm{O}\right.$ and $\left.\delta^{13} \mathrm{C}\right)$ : the case of Lake Neuchatel (Switzerland). Palaeogeogr. Palaeoclimatol. Palaeoecol., 140: 33-50.

Fischer, A. 1996. Isotopengeochemische Untersuchungen $\left(\delta^{18} O\right.$ und $\left.\delta^{13} C\right)$ im Wasser und in den Sedimenten des Soppensees (Kt. Luzern, Schweiz Klimaänderungen und Entwicklungsgeschichte des Sees seit dem Spätglazial. Ph.D. thesis. Swiss Federal Institute of Technology Zürich.

Fronval, T., N.B. Jensen \& B. Buchardt. 1995. Oxygen isotope disequilibrium precipitation of calcite in Lake Aresso, Denmark. Geology, 23: 463-466.

Gat, J.R. 1981a. Groundwater. In: J.R. Gat \& R. Gonfiantini (Eds), Stable isotope hydrology - Deuterium and oxygen18 in the water cycle. International Atomic Energy Agency: 223-241.

Gat, J.R. 1981b. Lakes. In: J. R. Gat and R. Gonfiantini (Eds), Stable isotope hydrology - Deuterium and oxygen-18 in the water cycle. International Atomic Energy Agency: 203-221.

Haskell, B.J., D.R. Engstrom \& S.C. Fritz. 1996. Late Quaternary paleohydrology in the North American Great Plains inferred from the geochemistry of endogenic carbonate and fossil ostracodes from Devils Lake, North Dakota, USA. Palaeogeogr. Palaeoclimatol. Palaeoecol., 124: 179-193. 
Hodell, D.A., C.L. Schelske, G.L. Fahnenstiel \& L.L. Robbins. 1998. Biologically induced calcite and its isotopic composition in Lake Ontario. Limnol. Oceanogr., 43: 187-199.

Holmes, J.A. \& A.R. Chivas. 2002. Ostracod shell chemistry Overview. In: J.A. Holmes \& A.R. Chivas (Eds), The Ostracoda - Applications in quaternary research. AGU: 185-204.

Kim, S.-T. \& J.R. O'neil. 1997. Equilibrium and nonequilibrium oxygen isotope effects in synthetic carbonates. Geochim. Cosmochim. Acta, 61: 3461-3475.

Kirilova, E.P., P.Bluszcz, O.Heiri, H.Cremer, C.Ohlendorf, A.F. Lotter \& B. Zolitschka. 2008. Seasonal and interannual dynamics of diatom assemblages in Sacrower See (NE Germany): a sediment trap study. Hydrobiologia, 614: 159-170. doi:10.1007/s10750-008-9504-z.

Lee, C., J.A. Mckenzie \& M. Sturm. 1987. Carbon isotope fractionation and changes in the flux and composition of particulate matter resulting from biological activity during a sediment trap experiment in Lake Greifen, Switzerland. Limnol. Oceanogr., 32: 83-96.

Lemcke, G. \& M. Sturm. 1997. $\delta^{18} \mathrm{O}$ and trace element measurements as proxy for the reconstruction of climate changes at Lake Van (Turkey): Preliminary results. In: $\mathrm{H}$. Nüzhet Dalfes \& G. Kukla (Eds), Third millenium BC climate change and old world collapse. NATO ASI Vol. I 49: 653-678.

Leng, M.J. \& J.D. Marshall. 2004. Palaeoclimate interpretation of stable isotope data from lake sediment archives. Quat. Sci. Rev., 23: 811-831. doi:10.1016/j. quascirev.2003.06.012

Lüder, B., G. Kirchner, A. Lücke \& B. Zolitschka. 2006. Palaeonvironmental reconstructions based on geochemical parameters from annually laminated sediments of Sacrower See (northeastern Germany) since the 17 th century. J. Paleolimnol., 35: 897-912. doi:10.1017/ s10933005.6188-5

Massmann, G., A. Knappe, D. Richter \& P. Asaf. 2004. Investigating the influence of treated sewage on groundwater and surface water using wastewater indicators in Berlin, Germany. Acta Hydrochim. Hydrobiol., 32: 336-350. doi:10.1002/aheh.200400543

McConnaughey, T. $1989 .{ }^{13} \mathrm{C}$ and ${ }^{18} \mathrm{O}$ isotopic disequilimbrium in biological carbonates: I. Patterns. Geochim. Cosmochim. Acta, 53: 151-162.

McDermott, F. 2004. Palaeo-climate reconstruction from stable isotope variations in speleothems: a review. Quat. Sci. Rev., 23: 901-918. doi:10.1016/j.quascirev.2003.06.021

McKenzie, J.A. 1985. Carbon isotopes and productivity in the lacustrine and marine environment. In: W. Stumm (Ed.), Chemical processes in lakes. Wiley: 99-118.

Mitsuguchi, T., E. Matsumoto, O. Abe, T. Uchid \& P.J. Isdale. 1996. Mg/Ca Thermometry in Coral Skeletons. Science, 274: $961-963$.

Müller, G., G. Irion \& U. Förstner. 1972. Formation and diagenesis of inorganic $\mathrm{Ca}-\mathrm{Mg}$ carbonates in the lacustrine environment. Naturwissenschaften, 59: 158-164.

Niessen, F. \& M. Sturm. 1987. Die Sedimente des Baldeggersees (Schweiz) - Ablagerungsraum und Eutrophierungsentwicklung während der letzten 100 Jahre. Arch. Hydrobiol., 108: 365-383.

Ohlendorf, C. \& M. Sturm. 2001. Precipitation and dissolution of calcite in a Swiss high alpine lake. Arct. Antarct. Alp. Research, 33: 410-417

Received: June 2008

Accepted: April 2009
Pearson, F.J. \& T.B. Coplen. 1978. Stable Isotope Studies of Lakes. In: A. Lerman (Ed.), Lakes - Chemistry, Geology, Physics.. Springer: 325-339.

Rümmler, F., S. Schiewe \& H. Ebel. 1997. Arbeitsbericht 1997 zur wissenschaftlichen Begleitung der Sanierung des Sacrower Sees mittels Tiefenwasserbelüftung. Institut für Binnenfischerei e. V. Potsdam-Sacrow: $41 \mathrm{pp}$.

Schelske, C. L. \& D.A. Hodell. 1991. Recent changes in productivity and climate of Lake Ontario detected by isotopic analysis of sediments. Limnol. Oceanogr., 36: 961-975.

Schönfelder, I. 1997. Eine Phosphor-Diatomeen-Relation für alkalische Seen und Flüsse Brandenburgs und ihre Anwendung für die paläolimnologische Analyse von Auensedimenten der unteren Havel. Dissertationes Botanicae, 283: 1-148.

Skidmore, M., M. Sharp \& M. Tranter. 2004. Kinetic isotopic fractionation during carbonate dissolution in laboratory experiments: implications for detection of microbial $\mathrm{CO}_{2}$ signatures using $\delta^{13} \mathrm{C}$-DIC. Geochim. Cosmochim. Acta, 68: 4309-4317. doi:10.1016/j.gca.2003.09.024

Stuiver, M. 1970. Oxygen and carbon Isotope ratios of freshwater carbonates as climatic indicators. J. Geophys. Res., 75: 5247-5257.

Tarutani, T., R.N. Clayton, and T.K. Mayeda. 1969. The effect of polymorphism and magnesium substitution on oxygen isotope fractionation between calcium carbonate and water. Geochim. Cosmochim. Acta, 33: 987-996.

Talbot, M.R. 1990. A review of the Palaeohydrological interpretation of carbon and oxygen isotopic ratios in primary lacustrine carbonates. Chem. Geol., 80: 261-279.

Teranes, J.L. \& S.M. Bernasconi. 2005. Factors controlling $\delta^{13} \mathrm{C}$ values of sedimentary carbon in hypertrophic Baldeggersee, Switzerland, and implications for interpreting isotope excursions in lake sedimentary records. Limnol. Oceanogr., 50: 914-922.

Teranes, J.L., J.A. Mckenzie, S.M. Bernasconi, A.F. Lotter \& M. Sturm. 1999a. A study of oxygen isotopic fractionation during bio-induced calcite precipitation in eutrophic Baldeggersee, Switzerland. Geochim. Cosmochim. Acta, 63: 1981-1989.

Teranes, J.L., J.A. Mckenzie, A.F. Lotter \& M. Sturm. 1999b. Stable iotope response to lake eutrophication: Calibration of a high-resolution lacustrine sequence from Baldeggersee, Switzerland. Limnol. Oceanogr., 44: 320-333.

Von Grafenstein, U., H. Erlenkeuser, J. Müller \& A. Kleinmann-Eisenmann. 1992. Oxygen isotope records of benthic ostracods in Bavarian lake sediments. Naturwissenschaften, 79: 145-192.

Wefer, G., W.H. Berger, J. Bijma \&G. Fischer. 1999. Clues to Ocean History: a Brief Overview of Proxies. In: Fischer \& Wefer (Eds), Use of Proxies in Paleoceanography: Examples from the South Atlantic. Springer Verlag: 1-68.

Wetzel, R.G. 2001. Limnology. Academic Press, San Diego

Wick, L., G. Lemcke \& M. Sturm. 2003. Evidence of Lateglacial and Holocene climatic change and human impact in eastern Anatolia: high-resolution pollen, charcoal isotopic and geochemical records from the laminated sediments of Lake Van, Turkey. Holocene, 13: 665-675. doi:10.1191/ 0959683603hl653rp. 